\title{
Synthesis of the Fused Polyether Core of Hemibrevetoxin B \\ by Two-directional Ring-closing Metathesis
}

J. Stephen Clark, ${ }^{* \dagger}$ Damian M. Grainger, ${ }^{\ddagger}$ Alexandra A.-C. Ehkirch, ${ }^{\ddagger}$ Alexander J. Blake ${ }^{\ddagger}$ and Claire Wilson

$\dagger$ WestCHEM, Department of Chemistry, Joseph Black Building, University of Glasgow, University Avenue, Glasgow G12 8QQ, UK

*School of Chemistry, University of Nottingham, University Park, Nottingham NG7 2RD, UK

\section{Supporting Information}

\section{Oxepenone 6}

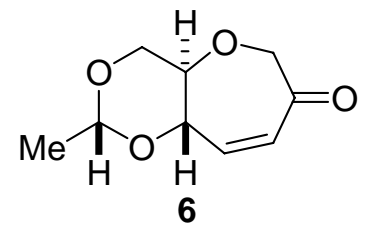

The ruthenium catalyst $5(150 \mathrm{mg}, 0.178 \mathrm{mmol})$ was added to a solution of enone $4(1.50 \mathrm{~g}, 7.14 \mathrm{mmol})$ in $\mathrm{CH}_{2} \mathrm{Cl}_{2}(800 \mathrm{~mL})$ and the reaction was heated at reflux for $18 \mathrm{~h}$. The solvent was then removed in vacuo and the residue was purified by flash chromatography on silica gel ( $\mathrm{Et}_{2} \mathrm{O}$-petrol, 1:3 then 1:1) to give the oxapenone $6(1.21 \mathrm{~g}, 94 \%)$ as a colorless crystalline solid: $\mathrm{Mp}=87-88^{\circ} \mathrm{C}$ (recrystallized from $\mathrm{Et}_{2} \mathrm{O}$-petrol); $\mathrm{R}_{f}=0.36\left(\mathrm{Et}_{2} \mathrm{O}-\right.$ petrol, 1:3); $[\alpha]_{\mathrm{D}}{ }^{21}=+98\left(c=1.0, \mathrm{CHCl}_{3}\right) ; \mathrm{IR}\left(\mathrm{CHCl}_{3}\right) v_{\max } 2993,2931$, 2867, 2689, 1667, 982, 905, 881, 844; ${ }^{1} \mathrm{H}$ NMR (500 MHz) $\delta 1.37$ (3H, d, $\left.J=5.1 \mathrm{~Hz}\right), 3.50(1 \mathrm{H}, \mathrm{dd}, J=$ 10.5, 10.1 Hz), $3.57(1 \mathrm{H}, \mathrm{ddd}, J=10.1,8.8,4.9 \mathrm{~Hz}), 4.19(1 \mathrm{H}, \mathrm{dd}, J=10.5,4.9 \mathrm{~Hz}), 4.22(1 \mathrm{H}, \mathrm{ddd}, J=$ 8.8, 2.7, $2.2 \mathrm{~Hz}), 4.26(1 \mathrm{H}, \mathrm{d}, J=18.1 \mathrm{~Hz}), 4.39(1 \mathrm{H}, \mathrm{d}, J=18.1 \mathrm{~Hz}), 4.75(1 \mathrm{H}, \mathrm{q}, J=5.1 \mathrm{~Hz}), 6.05(1 \mathrm{H}$, $\mathrm{dd}, J=12.8,2.7 \mathrm{~Hz}), 6.52(1 \mathrm{H}, \mathrm{dd}, J=12.8,2.2 \mathrm{~Hz}) ;{ }^{13} \mathrm{C} \mathrm{NMR}(125 \mathrm{MHz}) 20.3\left(\mathrm{CH}_{3}\right), 68.4\left(\mathrm{CH}_{2}\right), 74.9$ $(\mathrm{CH}), 77.5\left(\mathrm{CH}_{2}\right), 80.0(\mathrm{CH}), 99.5(\mathrm{CH}), 128.5(\mathrm{CH}), 145.0(\mathrm{CH}), 200.8(\mathrm{C})$; LRMS (EI) m/z 185 (53), 140 (46), 123 (15), 97 (33), 82 (17), 68 (21), 57 (100); HRMS (EI): calcd for $\mathrm{C}_{9} \mathrm{H}_{13} \mathrm{O}_{4}\left([\mathrm{M}+\mathrm{H}]^{+}\right)$: 185.0814, found: 185.0808 [ $\Delta 3.2 \mathrm{ppm}]$. Found $\mathrm{C}, 58.68 ; \mathrm{H}, 6.58 ; \mathrm{C}_{9} \mathrm{H}_{12} \mathrm{O}_{4}$ requires $\mathrm{C}, 58.69 ; \mathrm{H}, 6.57$. 


\section{Diol 10}

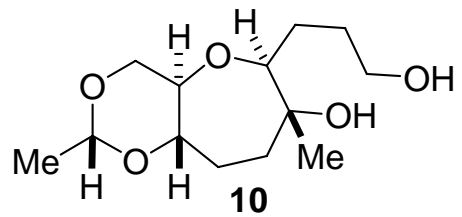

Methylmagnesium bromide (1.43 $\mathrm{mL}$ of a 1.4 M THF-PhMe [1:3] solution, $2.0 \mathrm{mmol}$ ) was added to a solution of ketone $9(107 \mathrm{mg}, 0.322 \mathrm{mmol})$ in toluene $(10 \mathrm{~mL})$ at $-78{ }^{\circ} \mathrm{C}$. After stirring at $-78{ }^{\circ} \mathrm{C}$ for 0.5 $\mathrm{h}$ the reaction was quenched at this temperature by the addition of $\mathrm{MeOH}(1 \mathrm{~mL})$. The reaction was allowed to warm to $\mathrm{rt}$ and the solvent was removed in vacuo. The residue was purified by flash chromatography on silica gel $\left(\mathrm{Et}_{2} \mathrm{O}-\right.$ petrol, $\left.1: 1\right)$ to give the tertiary allylic alcohol $(104 \mathrm{mg}, 93 \%)$ as a colorless oil.

The tertiary allylic alcohol $(85 \mathrm{mg}, 0.24 \mathrm{mmol})$ was dissolved in $\mathrm{MeOH}$ and $\mathrm{Pd}(\mathrm{OH})_{2}(20 \%$ on carbon $)$ (17 mg, $0.024 \mathrm{mmol}$ ) was added. The reaction was stirred vigorously and placed under an atmosphere of hydrogen for a period of $1 \mathrm{~h}$. The solids were removed by filtration through Celite and the solvent was then removed in vacuo to give the diol $10(63 \mathrm{mg}, 99 \%)$ as a colorless oil. The sample solidified on standing and crystals suitable for X-ray analysis were obtained by recrystallization from $\mathrm{CH}_{2} \mathrm{Cl}_{2}$ and hexane: $\mathrm{Mp}=87-89^{\circ} \mathrm{C}$ (recrystallized from $\mathrm{CH}_{2} \mathrm{Cl}_{2}$-hexane); $\mathrm{R}_{f}=0.23(\mathrm{EtOAc}) ;[\alpha]_{\mathrm{D}}{ }^{25}=-14(c=0.5$, $\left.\mathrm{CHCl}_{3}\right)$; IR $\left(\mathrm{CHCl}_{3}\right) v_{\max } 3607,2939,2869,1602,982,898 ;{ }^{1} \mathrm{H}$ NMR (400 MHz) $\delta 1.14(3 \mathrm{H}, \mathrm{s}), 1.32$ $(3 \mathrm{H}, \mathrm{d}, J=5.1 \mathrm{~Hz}), 1.35-1.43(1 \mathrm{H}, \mathrm{m}), 1.55-1.64(1 \mathrm{H}, \mathrm{m}), 1.69-1.82(3 \mathrm{H}, \mathrm{m}), 1.83-1.99(3 \mathrm{H}, \mathrm{m}), 2.20$ $(2 \mathrm{H}, \mathrm{s}), 3.26-3.42(4 \mathrm{H}, \mathrm{m}), 3.60-3.73(2 \mathrm{H}, \mathrm{m}), 4.09(1 \mathrm{H}, \mathrm{dd}, J=10.0,3.6 \mathrm{~Hz}), 4.63(1 \mathrm{H}, \mathrm{q}, J=5.1 \mathrm{~Hz})$; ${ }^{13} \mathrm{C}$ NMR (100 MHz) $20.4\left(\mathrm{CH}_{3}\right), 23.8\left(\mathrm{CH}_{3}\right), 26.6\left(\mathrm{CH}_{2}\right), 27.4\left(\mathrm{CH}_{2}\right), 29.8\left(\mathrm{CH}_{2}\right), 39.3\left(\mathrm{CH}_{2}\right), 62.5$ $\left(\mathrm{CH}_{2}\right), 69.2\left(\mathrm{CH}_{2}\right), 74.9(\mathrm{C}), 77.4(\mathrm{CH}), 82.4(\mathrm{CH}), 88.5(\mathrm{CH}), 99.0(\mathrm{CH})$; LRMS (EI+): m/z $259\left(\mathrm{M}-\mathrm{H}^{+}\right.$, 40), 242 (100); HRMS (EI+): calcd for $\mathrm{C}_{13} \mathrm{H}_{23} \mathrm{O}_{5}\left([\mathrm{M}-\mathrm{H}]^{+}\right)$259.1545, found 259.1558 [ $\left.\Delta-4.6 \mathrm{ppm}\right]$. Found C, 59.48; H, 9.37; $\mathrm{C}_{13} \mathrm{H}_{24} \mathrm{O}_{5}$ requires C, 59.98; H, 9.29.

\section{Alkene 11}

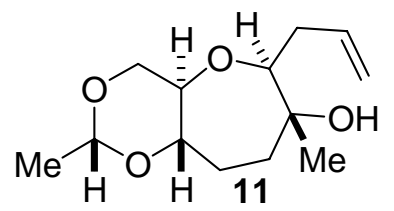

A flask containing the diol $10(99 \mathrm{mg}, 0.381 \mathrm{mmol})$ and 2-nitrophenylselenocyanate $(173 \mathrm{mg}, 0.762$ mmol, recrystallised from EtOH) was placed under high vacuum for $0.5 \mathrm{~h}$ and then flushed with argon. THF $(10 \mathrm{~mL})$ was introduced followed by tri- $n$-butylphosphine $(154 \mathrm{mg}, 0.762 \mathrm{mmol})$ and the mixture was stirred at $\mathrm{rt}$ for $0.5 \mathrm{~h}$. Solid $\mathrm{NaHCO}_{3}(187 \mathrm{mg}, 2.226 \mathrm{mmol})$ was added and the mixture was cooled in an ice bath. Hydrogen peroxide ( $1 \mathrm{~mL}$ of a $35 \%$ aqueous solution) was added and the reaction was then 
warmed to $40{ }^{\circ} \mathrm{C}$ for $2 \mathrm{~h}$. The reaction mixture was partitioned between EtOAc $(100 \mathrm{~mL})$ and a sat. aqueous solution of $\mathrm{Na}_{2} \mathrm{CO}_{3}(100 \mathrm{~mL})$ and the phases were separated. The organic layer was washed with brine $(50 \mathrm{~mL})$, then dried $\left(\mathrm{MgSO}_{4}\right)$ and concentrated in vacuo. Purification by flash chromatography on silica gel $\left(\mathrm{Et}_{2} \mathrm{O}\right.$-petrol, 1:3 then 1:1) gave the alkene $\mathbf{1 1}(75 \mathrm{mg}, 85 \%)$ as a colorless oil: $\mathrm{R}_{f}=0.23\left(\mathrm{Et}_{2} \mathrm{O}\right.$ petrol, 1:1); $[\alpha]_{\mathrm{D}}^{25}=-20\left(c=1.0, \mathrm{CHCl}_{3}\right)$; IR $\left(\mathrm{CHCl}_{3}\right) v_{\max } 3606,2939,2868,1704,1641,1602,993$, 969, 952, 898, 875, $840 ;{ }^{1} \mathrm{H}$ NMR (400 MHz) $\delta 1.17(3 \mathrm{H}, \mathrm{s}), 1.33(3 \mathrm{H}, \mathrm{d}, J=5.1 \mathrm{~Hz}), 1.73-1.82(1 \mathrm{H}$, m), 1.87-1.98 (3H, m), 2.12 (1H, dddt, $J=14.4,10.2,6.6,1.4 \mathrm{~Hz}), 2.35$ (1H, dddt, $J=14.4,7.1,2.7,1.2$ $\mathrm{Hz}), 3.27-3.42(4 \mathrm{H}, \mathrm{m}), 4.06-4.09(1 \mathrm{H}, \mathrm{m}), 4.64(1 \mathrm{H}, \mathrm{q}, J=5.1 \mathrm{~Hz}), 5.06(1 \mathrm{H}, \mathrm{ddt}, J=10.2,1.9,1.2$ $\mathrm{Hz}), 5.11(1 \mathrm{H}, \mathrm{ddt}, J=17.2,1.9,1.4 \mathrm{~Hz}), 5.86(1 \mathrm{H}, \mathrm{dddd}, J=17.2,10.2,7.1,6.6 \mathrm{~Hz}) ;{ }^{13} \mathrm{C} \mathrm{NMR}(100$ MHz) $20.5\left(\mathrm{CH}_{3}\right), 23.9\left(\mathrm{CH}_{3}\right), 27.4\left(\mathrm{CH}_{2}\right), 35.0\left(\mathrm{CH}_{2}\right), 39.4\left(\mathrm{CH}_{2}\right), 69.2\left(\mathrm{CH}_{2}\right), 74.9(\mathrm{C}), 77.6(\mathrm{CH}), 82.5$ $(\mathrm{CH}), 88.2(\mathrm{CH}), 99.0(\mathrm{CH}), 116.8\left(\mathrm{CH}_{2}\right), 135.8(\mathrm{CH})$.

\section{Lactone 14}

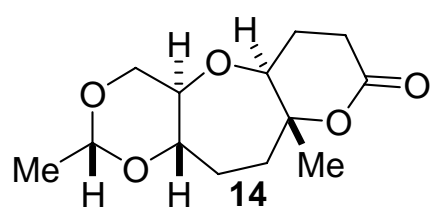

Potassium bromide ( $20 \mu \mathrm{L}$ of a $1 \mathrm{M}$ aqueous solution, $0.020 \mathrm{mmol}$ ) was added to a solution of diol 10 (52 $\mathrm{mg}, 0.20 \mathrm{mmol})$ in $\mathrm{CH}_{2} \mathrm{Cl}_{2}$ and the mixture was cooled to $0{ }^{\circ} \mathrm{C}$. TEMPO $(6 \mathrm{mg}, 0.04 \mathrm{mmol})$ was added to the vigorously stirred solution, followed by the dropwise addition of a $\mathrm{NaOCl}$ solution in sat. aqueous $\mathrm{NaHCO}_{3}\left(\sim 0.3 \mathrm{M}, 1: 1\right.$ mixture of commercial bleach and sat. aqueous $\mathrm{NaHCO}_{3}$ solution) and the reaction mixture was stirred for $1 \mathrm{~h}$. $\mathrm{Na}_{2} \mathrm{SO}_{3}(252 \mathrm{mg}, 2.0 \mathrm{mmol})$ was then added and stirring was continued for a further $1 \mathrm{~h}$. The reaction mixture was extracted with $\mathrm{Et}_{2} \mathrm{O}(30 \mathrm{~mL})$ and the organic extracts were then washed with brine $(10 \mathrm{~mL})$ and dried $\left(\mathrm{MgSO}_{4}\right)$. The solvent was removed in vacuo and the residue was purified by flash chromatography on silica gel $\left(\mathrm{Et}_{2} \mathrm{O}\right)$ to afford the lactone $14(44 \mathrm{mg}, 86 \%)$ as a colorless crystalline solid. Crystals suitable for X-ray analysis were obtained by recrystallization from $\mathrm{CH}_{2} \mathrm{Cl}_{2}$ and hexane: $\mathrm{Mp}=104-105^{\circ} \mathrm{C}$ (recrystallized from $\mathrm{CH}_{2} \mathrm{Cl}_{2}$-hexane); $\mathrm{R}_{f}=0.62\left(\mathrm{Et}_{2} \mathrm{O}\right) ;[\alpha]_{\mathrm{D}}{ }^{26}=+32(c=1.0$, $\left.\mathrm{CHCl}_{3}\right)$; IR $\left(\mathrm{CHCl}_{3}\right) v_{\max } 2942,2867,1729,979,905 ;{ }^{1} \mathrm{H} \mathrm{NMR}(400 \mathrm{MHz}) \delta 1.31(3 \mathrm{H}, \mathrm{d}, J=5.1 \mathrm{~Hz})$, $1.35(3 \mathrm{H}, \mathrm{s}), 1.81-1.94(3 \mathrm{H}, \mathrm{m}), 1.95-2.04(1 \mathrm{H}, \mathrm{m}), 2.07-2.27(2 \mathrm{H}, \mathrm{m}), 2.63(1 \mathrm{H}, \mathrm{ddd}, J=19.1,9.6,8.9$ Hz), 2.73 (1H, ddd, $J=19.1,9.0,2.7 \mathrm{~Hz}), 3.33-3.40(1 \mathrm{H}, \mathrm{m}), 3.42-3.49(2 \mathrm{H}, \mathrm{m}), 3.65$ (1H, dd, $J=12.0$, $5.3 \mathrm{~Hz}), 4.11(1 \mathrm{H}, \mathrm{dd}, J=10.7,4.4 \mathrm{~Hz}), 4.60(1 \mathrm{H}, \mathrm{q}, J=5.1 \mathrm{~Hz}) ;{ }^{13} \mathrm{C}$ NMR $(100 \mathrm{MHz}) 20.4\left(\mathrm{CH}_{3}\right), 20.7$ $\left(\mathrm{CH}_{3}\right), 22.6\left(\mathrm{CH}_{2}\right), 27.5\left(\mathrm{CH}_{2}\right), 28.0\left(\mathrm{CH}_{2}\right), 37.2\left(\mathrm{CH}_{2}\right), 69.0\left(\mathrm{CH}_{2}\right), 74.5(\mathrm{CH}), 80.3(\mathrm{CH}), 80.4(\mathrm{CH})$, $83.6(\mathrm{C}), 98.8(\mathrm{CH}), 170.3(\mathrm{C})$; LRMS (EI+): m/z $255\left([\mathrm{M}-\mathrm{H}]^{+}, 6\right), 212$ (32), 184 (18), 169 (48), 151 (31), 127 (33), 99 (16), 84 (29), 70 (100); HRMS (EI+): calcd for $\mathrm{C}_{13} \mathrm{H}_{19} \mathrm{O}_{5}\left([\mathrm{M}-\mathrm{H}]^{+}\right)$255.1232, found $255.1225[\Delta 2.9 \mathrm{ppm}]$. Found $\mathrm{C}, 60.80 ; \mathrm{H}, 7.93 ; \mathrm{C}_{13} \mathrm{H}_{20} \mathrm{O}_{5}$ requires $\mathrm{C}, 60.92 ; \mathrm{H}, 7.87$. 


\section{Diene 13}

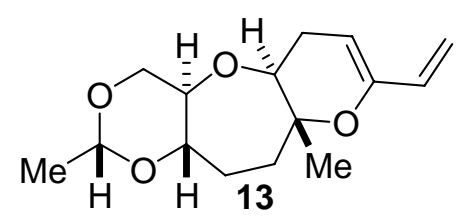

\section{From the alcohol 11}

A solution of alcohol $11(217 \mathrm{mg}, 0.897 \mathrm{mmol})$ in THF (5 mL) was added to a suspension of potassium hydride (359 mg, $2.69 \mathrm{mmol})$ in THF $(6 \mathrm{~mL})$ and the mixture was stirred at $\mathrm{rt}$ for $0.5 \mathrm{~h}$. Trichloroethene (94 $\mu \mathrm{L}, 136 \mathrm{mg}, 1.02 \mathrm{mmol}$ ) was added and the mixture was stirred for a further $0.5 \mathrm{~h}$. The reaction was quenched by the addition of water $(3 \mathrm{~mL})$ and $\mathrm{Et}_{2} \mathrm{O}(10 \mathrm{~mL})$ was then added. The phases were separated and the aqueous phase was extracted with $\mathrm{CH}_{2} \mathrm{Cl}_{2}(2 \times 10 \mathrm{~mL})$. The combined organic extracts were dried $\left(\mathrm{MgSO}_{4}\right)$ and the solvent was removed in vacuo. Purification of the residue by flash chromatography on silica gel (petrol then $\mathrm{Et}_{2} \mathrm{O}$-petrol, 1:3) gave the chlorinated enol ethers (isomeric mixture) (297 mg, 98\%) as a colorless oil.

The chlorinated enol ethers $(43 \mathrm{mg}, 0.128 \mathrm{mmol})$ were dissolved in $\mathrm{Et}_{2} \mathrm{O}(2 \mathrm{~mL})$ and the solution was cooled to $-78^{\circ} \mathrm{C}$. $n$-BuLi ( $140 \mu \mathrm{L}$ of a $2.5 \mathrm{M}$ solution in hexanes, $\left.0.350 \mathrm{mmol}\right)$ was then added carefully and the reaction was warmed to $-40{ }^{\circ} \mathrm{C}$ for $1 \mathrm{~h}$. The reaction was quenched by the addition of sat. aqueous $\mathrm{NH}_{4} \mathrm{Cl}$ solution $(0.5 \mathrm{~mL})$ and $\mathrm{Et}_{2} \mathrm{O}(20 \mathrm{~mL})$ was added. The layers were separated and the organic layer was dried over $\left(\mathrm{MgSO}_{4}\right)$ and the solvent removed in vacuo taking care to avoid heating. The crude alkynyl ether 12 was prone to decomposition and was used immediately in the next step without purification.

Ethylene was bubbled through a solution of the ruthenium catalyst $5(19.8 \mathrm{mg}, 0.023 \mathrm{mmol})$ in toluene (8 $\mathrm{mL}$ ) for a period of $10 \mathrm{~min}$. A solution of the enyne 12 [34 $\mathrm{mg}, 0.128 \mathrm{mmol}$ (assumed maximum theoretical yield)] in toluene $(2 \mathrm{~mL})$ was added and the reaction placed in a pre-heated oil bath at $70{ }^{\circ} \mathrm{C}$. The mixture was heated at this temperature for $0.5 \mathrm{~h}$ and the solvent was removed in vacuo. The residue was purified by flash chromatography on silica gel $\left(\mathrm{Et}_{2} \mathrm{O}\right.$-petrol, 1:4) to provide the diene 13 (20.4 mg, $66 \%$ yield over 2 steps) as a colorless liquid.

\section{From the lactone 14}

The lactone 14 (350 mg, $1.37 \mathrm{mmol}$ ) and $N$-phenylbis(trifluoromethanesulfonimide) (952 mg, $2.66 \mathrm{mmol}$ ) were dissolved in THF $(27 \mathrm{~mL})$ and the solution was cooled to $-78{ }^{\circ} \mathrm{C}$. DMPU $(488 \mu \mathrm{L})$ was then added followed by KHMDS (6.7 $\mathrm{mL}$ of $0.5 \mathrm{M}$ solution in toluene, $3.35 \mathrm{mmol}$ ) over a period of $5 \mathrm{~min}$. After $1 \mathrm{~h}$, the reaction was quenched by the addition of water $(10 \mathrm{~mL})$ and warmed to rt. The phases were separated and the aqueous phase was extracted with $\mathrm{Et}_{2} \mathrm{O}(60 \mathrm{~mL})$. The combined organic extracts were then washed with brine $(100 \mathrm{~mL})$ and the solvent was removed in vacuo. The residue was purified by flash 
chromatography on silica gel $\left(\mathrm{Et}_{2} \mathrm{O}\right.$-petrol, $\left.1: 4+1 \% \mathrm{Et}_{3} \mathrm{~N}\right)$ to give the triflate 15 which was used immediately in the next step (CAUTION: care must be taken not to concentrate the product because it decomposes rapidly when isolated).

The triflate $15(\sim 1.37 \mathrm{mmol})$ was dissolved in THF $(14 \mathrm{~mL})$ and tri-n-butyl(vinyl)tin $(1.2 \mathrm{~mL}, 4.11$ mmol), $\mathrm{LiCl}(348 \mathrm{mg}, 8.21 \mathrm{mmol})$ and $\mathrm{Pd}\left(\mathrm{PPh}_{3}\right)_{4}(158 \mathrm{mg}, 0.137 \mathrm{mmol})$ were added sequentially. The reaction was then heated to $80{ }^{\circ} \mathrm{C}$ for $1.5 \mathrm{~h}$ and then allowed to cool to $\mathrm{rt}$. The reaction mixture was diluted with $\mathrm{Et}_{2} \mathrm{O}(40 \mathrm{~mL})$, a $20 \%$ aqueous solution of potassium fluoride $(40 \mathrm{~mL})$ was added and the mixture was then stirred vigorously for $0.5 \mathrm{~h}$. The phases were separated and the aqueous phase was extracted with $\mathrm{Et}_{2} \mathrm{O}(2 \times 20 \mathrm{~mL})$. The combined organic extracts were dried $\left(\mathrm{MgSO}_{4}\right)$ and filtered, and the solvent was removed in vacuo. The residue was purified by flash chromatography (Et ${ }_{2} \mathrm{O}-$ petrol, 1:4) to give the diene 13 (315 $\mathrm{mg}, 87 \%$ over 2 steps) as colorless liquid.

$\mathrm{R}_{f}=0.48\left(\mathrm{Et}_{2} \mathrm{O}\right.$-petrol, 1:4); $[\alpha]_{\mathrm{D}}{ }^{26}=-106\left(c=0.25, \mathrm{CHCl}_{3}\right)$; IR $\left(\mathrm{CHCl}_{3}\right) v_{\max } 2940,2866,2337,1657$, 1602, 984, 913; ${ }^{1} \mathrm{H}$ NMR (500 MHz) $\delta 1.10(3 \mathrm{H}, \mathrm{s}), 1.33(3 \mathrm{H}, \mathrm{d}, J=5.1 \mathrm{~Hz}), 1.83-1.96(2 \mathrm{H}, \mathrm{m}), 2.04$ $(1 \mathrm{H}, \mathrm{dd}, J=16.6,11.0 \mathrm{~Hz}), 2.12-2.27(2 \mathrm{H}, \mathrm{m}), 2.31(1 \mathrm{H}, \mathrm{dt}, J=17.6,5.7 \mathrm{~Hz}), 3.34-3.40(1 \mathrm{H}, \mathrm{m})$, $3.41-3.50(2 \mathrm{H}, \mathrm{m}), 3.59(1 \mathrm{H}, \mathrm{dd}, J=10.6,6.0 \mathrm{~Hz}), 4.09-4.15(1 \mathrm{H}, \mathrm{m}), 4.62(1 \mathrm{H}, \mathrm{q}, J=5.1 \mathrm{~Hz}), 4.71$ $(1 \mathrm{H}, \mathrm{dd}, J=5.4,2.4 \mathrm{~Hz}),, 5.00(1 \mathrm{H}, \mathrm{d}, J=10.8 \mathrm{~Hz}), 5.43(1 \mathrm{H}, \mathrm{d}, J=17.1 \mathrm{~Hz}), 6.06(1 \mathrm{H}, \mathrm{dd}, J=17.1$, $10.8 \mathrm{~Hz}) ;{ }^{13} \mathrm{C}$ NMR (125 MHz) $16.3\left(\mathrm{CH}_{3}\right), 20.5\left(\mathrm{CH}_{3}\right), 26.7\left(\mathrm{CH}_{2}\right), 27.9\left(\mathrm{CH}_{2}\right), 37.0\left(\mathrm{CH}_{2}\right), 69.3\left(\mathrm{CH}_{2}\right)$, $74.1(\mathrm{CH}), 77.9(\mathrm{C}), 80.5(\mathrm{CH}), 81.1(\mathrm{CH}), 98.8(\mathrm{CH}), 99.9(\mathrm{CH}), 112.6\left(\mathrm{CH}_{2}\right), 132.2(\mathrm{CH}), 148.8(\mathrm{C})$; LRMS (ES+): m/z $348\left(\left[\mathrm{M}+\mathrm{Na}+\mathrm{MeCN}+\mathrm{H}_{2} \mathrm{O}\right]^{+}, 100\right), 307\left(\left[\mathrm{M}+\mathrm{Na}+\mathrm{H}_{2} \mathrm{O}\right]^{+}, 45\right), 267\left([\mathrm{M}+\mathrm{H}]^{+}, 93\right)$; HRMS (ES+): calcd for $\mathrm{C}_{15} \mathrm{H}_{24} \mathrm{O}_{5} \mathrm{Na}\left(\left[\mathrm{M}+\mathrm{Na}+\mathrm{H}_{2} \mathrm{O}\right]^{+}\right) 307.1521$, found 307.1517 [ $\left.\Delta 1.3 \mathrm{ppm}\right]$.

\section{Alcohol 18}

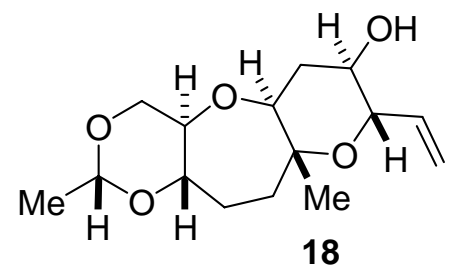

The diene 13 (42 mg, $0.158 \mathrm{mmol}$ ) was dissolved in $\mathrm{CH}_{2} \mathrm{Cl}_{2}(1.54 \mathrm{~mL})$ and the solution was cooled to $0{ }^{\circ} \mathrm{C}$. A cooled $\left(0{ }^{\circ} \mathrm{C}\right)$ solution of DMDO $(2.2 \mathrm{~mL}$ of a $\sim 0.07 \mathrm{M}$ solution in acetone, pre-dried over $\mathrm{K}_{2} \mathrm{CO}_{3}$ ) was added dropwise until TLC analysis indicated complete consumption of the starting material. The reaction was then concentrated in vacuo (CAUTION: temperature was maintained at $\leq 0{ }^{\circ} \mathrm{C}$ while the solvents were removed). The residue was dissolved in $\mathrm{CH}_{2} \mathrm{Cl}_{2}(6 \mathrm{~mL})$ and the solution was dried $\left(\mathrm{Na}_{2} \mathrm{SO}_{4}\right)$, then concentrated in vacuo $\left(\leq 0{ }^{\circ} \mathrm{C}\right)$. The crude material was placed under high vacuum for 0.5 $\mathrm{h}$ and then dissolved in THF $(3 \mathrm{~mL})$. The solution was cooled to $0{ }^{\circ} \mathrm{C}$ and then added to a solution of Super-Hydride ${ }^{\mathrm{TM}}$ in THF $(1 \mathrm{~mL})$ at $0^{\circ} \mathrm{C}$. The reaction was stirred for $20 \mathrm{~min}$ then quenched by the 
addition of water $(1 \mathrm{~mL})$, and the product was then extracted into $\mathrm{Et}_{2} \mathrm{O}(10 \mathrm{~mL})$. The organic layer was dried $\left(\mathrm{MgSO}_{4}\right)$ and the solvent was removed in vacuo. The residue was purified by flash column chromatography on silica gel ( $\mathrm{Et}_{2} \mathrm{O}$-petrol, 3:1) to deliver the alcohol $\mathbf{1 6}$ as a colorless liquid. The procedure was repeated twice (22 $\mathrm{mg}$ and $35 \mathrm{mg}$ of diene 13) and the products obtained were combined for the next step.

The alcohol $16(<0.372 \mathrm{mmol})$ was dissolved in $\mathrm{CH}_{2} \mathrm{Cl}_{2}(3.5 \mathrm{~mL})$ and the Dess-Martin periodinane (233 $\mathrm{mg}, 0.549 \mathrm{mmol}$ ) was added at $\mathrm{rt}$. The mixture was stirred for $13 \mathrm{~h}$ at $\mathrm{rt}$ and a further portion $(240 \mathrm{mg}$, $0.566 \mathrm{mmol})$ of the oxidant was added to the reaction followed by a third portion $(120 \mathrm{mg}, 0.283 \mathrm{mmol})$ after a further $2 \mathrm{~h}$. The reaction was then quenched by the addition of a sat. aqueous solution of $\mathrm{Na}_{2} \mathrm{~S}_{2} \mathrm{O}_{3}$ $(10 \mathrm{~mL})$ and the mixture stirred for $1 \mathrm{~h}$. The layers were then separated and the aqueous phase was extracted with $\mathrm{CH}_{2} \mathrm{Cl}_{2}(3 \times 10 \mathrm{~mL})$. The combined organic extracts were dried $\left(\mathrm{MgSO}_{4}\right)$ and the solvent was removed in vacuo. The crude product was dissolved in a mixture of $\mathrm{CH}_{2} \mathrm{Cl}_{2}$ and $\mathrm{MeOH}(1: 1,4 \mathrm{~mL})$ and $\mathrm{NaBH}_{4}(53 \mathrm{mg}, 1.4 \mathrm{mmol})$ was then added. The reaction was stirred for $1 \mathrm{~h}$ at $\mathrm{rt}$ and then quenched by the addition of a sat. aqueous solution of $\mathrm{NH}_{4} \mathrm{Cl}(5 \mathrm{~mL})$. The reaction mixture was diluted with $\mathrm{CH}_{2} \mathrm{Cl}_{2}$ $(50 \mathrm{~mL})$ and the aqueous phase was removed and extracted with $\mathrm{CH}_{2} \mathrm{Cl}_{2}(50 \mathrm{~mL})$. The combined organic extracts were dried $\left(\mathrm{MgSO}_{4}\right)$ and the solvent was removed in vacuo. The residue was purified by flash chromatography ( $\mathrm{Et}_{2} \mathrm{O}$-petrol, 3:1) to furnish the alcohol 18 (71 mg, 68\% over 4 steps) as colorless liquid: $\mathrm{R}_{f}=0.47\left(\mathrm{Et}_{2} \mathrm{O}\right.$-petrol, 3:1); $[\alpha]_{\mathrm{D}}^{21}=-4.8\left(c=0.5, \mathrm{CHCl}_{3}\right) ; \mathrm{IR}\left(\mathrm{CHCl}_{3}\right) v_{\max } 3591,2943,2872,1732,995$, 966, 942, 908, 886, 872; ${ }^{1} \mathrm{H}$ NMR (500 MHz) $\delta 1.24(3 \mathrm{H}, \mathrm{s}), 1.32(3 \mathrm{H}, \mathrm{d}, J=5.1 \mathrm{~Hz}), 1.64(1 \mathrm{H}, \mathrm{q}, J=$ $11.7 \mathrm{~Hz}), 1.70(1 \mathrm{H}$, br s), 1.79-1.89 (2H, m), 1.94-2.01 (1H, m), 2.12-2.20 (2H, m), 3.32-3.43 (4H, m), 3.49-3.55 (1H, m), $3.71(1 \mathrm{H}, \mathrm{dd}, J=9.3,7.2 \mathrm{~Hz}), 4.10-4.13(1 \mathrm{H}, \mathrm{m}), 4.60(1 \mathrm{H}, \mathrm{q}, J=5.1 \mathrm{~Hz}), 5.32(1 \mathrm{H}$, $\mathrm{d}, J=10.4 \mathrm{~Hz}), 5.39(1 \mathrm{H}, \mathrm{d}, J=17.4 \mathrm{~Hz}), 5.79(1 \mathrm{H}, \mathrm{ddd}, J=17.4,10.4,7.2 \mathrm{~Hz}) ;{ }^{13} \mathrm{C}$ NMR $(125 \mathrm{MHz})$ $16.2\left(\mathrm{CH}_{3}\right), 20.5\left(\mathrm{CH}_{3}\right), 28.4\left(\mathrm{CH}_{2}\right), 34.5\left(\mathrm{CH}_{2}\right), 37.8\left(\mathrm{CH}_{2}\right), 69.2\left(\mathrm{CH}_{2}\right), 69.6(\mathrm{CH}), 74.3(\mathrm{CH}), 76.5$ $(\mathrm{CH}), 77.0(\mathrm{C}), 80.1(\mathrm{CH}), 81.8(\mathrm{CH}), 98.6(\mathrm{CH}), 119.3\left(\mathrm{CH}_{2}\right), 136.3(\mathrm{CH})$; LRMS (EI+): m/z 283 $\left([\mathrm{M}-\mathrm{H}]^{+}, 6\right), 227(18), 184(100), 127$ (51); HRMS (EI+): calcd for $\mathrm{C}_{15} \mathrm{H}_{23} \mathrm{O}_{5}\left([\mathrm{M}-\mathrm{H}]^{+}\right)$283.1545, found $283.1551[\Delta-2.1 \mathrm{ppm}]$. Found $\mathrm{C}, 63.37 ; \mathrm{H}, 8.64 ; \mathrm{C}_{15} \mathrm{H}_{24} \mathrm{O}_{5}$ requires $\mathrm{C}, 63.36 ; \mathrm{H}, 8.51$.

\section{Tetraene 22}

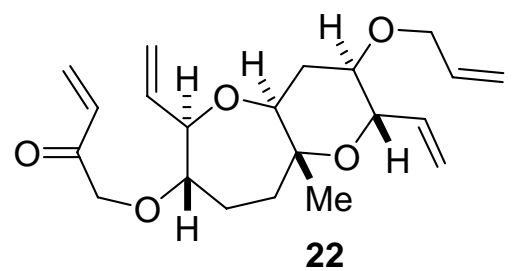

The silyl ether 21 ( $80 \mathrm{mg}, 0.20 \mathrm{mmol})$ was dissolved in THF ( $2 \mathrm{~mL})$ and TBAF ( $294 \mu \mathrm{L}$ of $1 \mathrm{M}$ solution in THF, $0.294 \mathrm{mmol}$ ) was added. The mixture was stirred at $\mathrm{rt}$ for $27 \mathrm{~h}$ and then $\mathrm{MeOH}(1 \mathrm{~mL})$ was 
added. The volatiles were removed in vacuo and the residue purified by flash chromatography on silica gel (petrol-Et $\left.\mathrm{E}_{2} \mathrm{O}, 1: 1\right)$ to give the secondary alcohol $(57.6 \mathrm{mg}, 100 \%)$ as a colorless oil.

The alcohol (44.7 mg, $0.152 \mathrm{mmol})$ was dissolved in DMF $(289 \mu \mathrm{L})$ and sodium hydride $(12.1 \mathrm{mg}$ of a $60 \%$ dispersion in mineral oil, $0.304 \mathrm{mmol}$ ) was added. The mixture was stirred for $15 \mathrm{~min}$ at $\mathrm{rt}$ and then the chloride 3 (64.2 $\mathrm{mg}, 0.182 \mathrm{mmol})$ was added. The reaction was stirred at $\mathrm{rt}$ for $2 \mathrm{~h}$ and then quenched by the addition of water $(3 \mathrm{~mL}) . \mathrm{Et}_{2} \mathrm{O}(15 \mathrm{~mL})$ was added and the two phases separated. The organic phase was washed with water $(3 \times 2 \mathrm{~mL})$ and the combined aqueous washings were extracted with $\mathrm{Et}_{2} \mathrm{O}$ $(3 \times 10 \mathrm{~mL})$. The organic extracts were combined and dried $\left(\mathrm{MgSO}_{4}\right)$, and solvent was removed in vacuo. The crude phosphonium ylide was then dissolved in a mixture of $\mathrm{Et}_{2} \mathrm{O}(760 \mu \mathrm{L})$ and phosphate buffer $(\mathrm{pH}$ $=7,190 \mu \mathrm{L})$. Formaldehyde $(17.1 \mu \mathrm{L}$ of a $37 \%$ aqueous solution, $0.228 \mathrm{mmol})$ was added to the vigorously stirred mixture and reaction was continued for $3 \mathrm{~h}$. After this time, $\mathrm{Et}_{2} \mathrm{O}(10 \mathrm{~mL})$ and water $(5$ $\mathrm{mL}$ ) were added to the mixture. The phases were separated and the aqueous phase was extracted with $\mathrm{Et}_{2} \mathrm{O}(2 \times 10 \mathrm{~mL})$. The combined organics were washed with brine $(5 \mathrm{~mL})$ and dried $\left(\mathrm{MgSO}_{4}\right)$, and the solvent was removed in vacuo. The residue was purified by flash chromatography on silica gel $\left(\mathrm{Et}_{2} \mathrm{O}-\right.$ petrol, 1:1) to deliver the starting alcohol $(3.2 \mathrm{mg}, 7 \%)$ and the tetraene $22(18.0 \mathrm{mg}, 33 \%)$ as a colorless oil: $\mathrm{R}_{f}=0.52\left(\mathrm{Et}_{2} \mathrm{O}\right.$-petrol, 1:1); $[\alpha]_{\mathrm{D}}{ }^{24}=-2.5\left(c=1.0, \mathrm{CHCl}_{3}\right) ; \mathrm{IR}\left(\mathrm{CHCl}_{3}\right) v_{\max } 3022,2930,2873,1699$, 1614, 990, 933; ${ }^{1} \mathrm{H}$ NMR (500 MHz) $\delta 1.27(3 \mathrm{H}, \mathrm{s}), 1.56-1.66(3 \mathrm{H}, \mathrm{m}), 1.80-1.93(\mathrm{~m}, 2 \mathrm{H}), 2.25(1 \mathrm{H}, \mathrm{dt}$, $J=12.0,4.8 \mathrm{~Hz}), 3.10(1 \mathrm{H}, \mathrm{ddd}, J=11.2,9.6,4.7 \mathrm{~Hz}), 3.60(1 \mathrm{H}, \mathrm{d}, J=6.5 \mathrm{~Hz}), 3.66(1 \mathrm{H}, \mathrm{dd}, J=12.2$, $4.7 \mathrm{~Hz}), 3.85(1 \mathrm{H}, \mathrm{dd}, J=9.2,6.4 \mathrm{~Hz}), 3.95(1 \mathrm{H}, \mathrm{dd}, J=12.7,5.6 \mathrm{~Hz}), 4.06(1 \mathrm{H}, \mathrm{dd}, J=12.7,5.6 \mathrm{~Hz})$, $4.15(1 \mathrm{H}, \mathrm{d}, J=16.8 \mathrm{~Hz}), 4.35(1 \mathrm{H}, \mathrm{d}, J=16.8 \mathrm{~Hz}), 4.41(1 \mathrm{H}, \mathrm{d}, J=4.2 \mathrm{~Hz}), 5.13(1 \mathrm{H}, \mathrm{d}, J=10.6 \mathrm{~Hz})$, $5.16(1 \mathrm{H}, \mathrm{d}, J=10.7 \mathrm{~Hz}), 5.22(1 \mathrm{H}, \mathrm{d}, J=10.5 \mathrm{~Hz}), 5.26(1 \mathrm{H}, \mathrm{dd}, J=17.2,1.5 \mathrm{~Hz}), 5.34(1 \mathrm{H}, \mathrm{d}, J=16.9$ $\mathrm{Hz}), 5.37(1 \mathrm{H}, \mathrm{d}, J=16.6 \mathrm{~Hz}), 5.76(1 \mathrm{H}, \mathrm{ddd}, J=17.1,10.7,5.5 \mathrm{~Hz}), 5.83-5.92(3 \mathrm{H}, \mathrm{m}), 6.37(1 \mathrm{H}, \mathrm{dd}, J$ $=17.6,1.2 \mathrm{~Hz}), 6.58(1 \mathrm{H}, \mathrm{dd}, J=17.6,10.7 \mathrm{~Hz}) ;{ }^{13} \mathrm{C} \mathrm{NMR}(125 \mathrm{MHz}) 15.5\left(\mathrm{CH}_{3}\right), 21.0\left(\mathrm{CH}_{2}\right), 33.3$ $\left(\mathrm{CH}_{2}\right), 34.4\left(\mathrm{CH}_{2}\right), 70.2\left(\mathrm{CH}_{2}\right), 72.8\left(\mathrm{CH}_{2}\right), 73.6(\mathrm{CH}), 75.8(\mathrm{CH}), 76.3(\mathrm{C}), 77.0(\mathrm{CH}), 82.9(\mathrm{CH}), 83.1$ $(\mathrm{CH}), 115.4\left(\mathrm{CH}_{2}\right), 117.0\left(\mathrm{CH}_{2}\right), 117.3\left(\mathrm{CH}_{2}\right), 129.3\left(\mathrm{CH}_{2}\right), 132.3(\mathrm{CH}), 134.9(\mathrm{CH}), 136.9(\mathrm{CH}), 137.0$ (CH), 196.9 (C); LRMS (ESI+): m/z $385\left([\mathrm{M}+\mathrm{Na}]^{+}, 100\right), 363\left([\mathrm{M}+\mathrm{H}]^{+}, 40\right)$; HRMS (ESI+): calculated for $\mathrm{C}_{21} \mathrm{H}_{30} \mathrm{O}_{5} \mathrm{Na}\left([\mathrm{M}+\mathrm{Na}]^{+}\right)$385.1985, found 385.1989 [ $\left.\Delta-1.1 \mathrm{ppm}\right]$.

\section{Tetracycle 23}

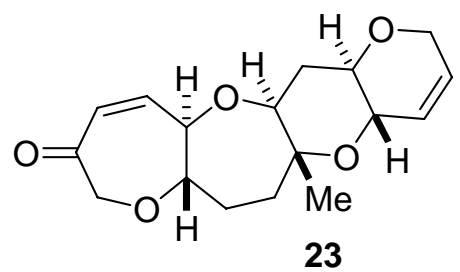

The tetraene $22(15.5 \mathrm{mg}, 0.043 \mathrm{mmol})$ was dissolved in $\mathrm{CH}_{2} \mathrm{Cl}_{2}(6.1 \mathrm{~mL})$ and the ruthenium complex 5 (3.6 mg, $0.004 \mathrm{mmol}$ ) was added. The solution was heated at reflux for $1 \mathrm{~h}$ and a further portion of 
ruthenium complex $5(3.6 \mathrm{mg}, 0.004 \mathrm{mmol})$ was added. The reaction was heated at reflux for an additional $1 \mathrm{~h}$ and the solvent was then removed in vacuo. The residue was purified by flash chromatography (petrol-Et $\left.{ }_{2} \mathrm{O}, 1: 1\right)$ to afford the tetracycle $23(9.6 \mathrm{mg}, 73 \%)$ as a colorless crystalline solid: $\mathrm{Mp}=140-142{ }^{\circ} \mathrm{C} ;[\alpha]_{\mathrm{D}}^{27}=-77\left(c=0.5, \mathrm{CHCl}_{3}\right) ; \mathrm{R}_{f}=0.29\left(\mathrm{Et}_{2} \mathrm{O}-\right.$ petrol, $\left.1: 1\right) ; \mathrm{IR}\left(\mathrm{CHCl}_{3}\right) v_{\max }$ 3036, 2954, 2879, 1672, 930, 810; ${ }^{1} \mathrm{H}$ NMR (400 MHz) $\delta 1.28(3 \mathrm{H}, \mathrm{s}), 1.78(1 \mathrm{H}, \mathrm{q}, J=11.8 \mathrm{~Hz})$, 1.82-1.90 (1H, m), 2.01-2.22 (4H, m), $3.17(1 \mathrm{H}, \mathrm{ddd}, J=12.6,8.6,4.2 \mathrm{~Hz}), 3.51(1 \mathrm{H}, \mathrm{td}, J=8.7,5.3$ $\mathrm{Hz}), 3.56(2 \mathrm{H}, \mathrm{dd}, J=11.9,4.2 \mathrm{~Hz}), 3.95(1 \mathrm{H}, \mathrm{m}), 4.18(1 \mathrm{H}, \mathrm{dt}, J=9.1,2.6 \mathrm{~Hz}), 4.22(1 \mathrm{H}, \mathrm{dd}, J=4.8$, $2.6 \mathrm{~Hz}), 4.22(1 \mathrm{H}, \mathrm{d}, J=18.4 \mathrm{~Hz}), 4.25-4.26(1 \mathrm{H}, \mathrm{m}), 4.32(1 \mathrm{H}, \mathrm{d}, J=18.4 \mathrm{~Hz}), 5.72(1 \mathrm{H}, \mathrm{ddd}, J=10.5$, 4.3, $2.4 \mathrm{~Hz}), 5.79(1 \mathrm{H}, \mathrm{d}, J=10.5 \mathrm{~Hz}), 5.97(1 \mathrm{H}, \mathrm{dd}, J=12.9,2.6 \mathrm{~Hz}), 6.57(1 \mathrm{H}, \mathrm{dd}, J=12.9,2.7 \mathrm{~Hz})$; ${ }^{13} \mathrm{C}$ NMR (100 MHz) $17.8\left(\mathrm{CH}_{3}\right), 30.0\left(\mathrm{CH}_{2}\right), 32.8\left(\mathrm{CH}_{2}\right), 38.0\left(\mathrm{CH}_{2}\right), 66.6\left(\mathrm{CH}_{2}\right), 67.9(\mathrm{CH}), 74.4(\mathrm{CH})$, $76.8\left(\mathrm{CH}_{2}\right), 77.6(\mathrm{C}), 82.0(\mathrm{CH}), 83.7(\mathrm{CH}), 83.8(\mathrm{CH}), 127.1(\mathrm{CH}), 127.1(\mathrm{CH}), 127.2(\mathrm{CH}), 146.9(\mathrm{CH})$, 201.9 (C); LRMS (ESI+): m/z $329\left([\mathrm{M}+\mathrm{Na}]^{+}, 66\right), 307\left([\mathrm{M}+\mathrm{H}]^{+}, 51\right), 289\left([\mathrm{M}+\mathrm{H}]^{+}-\mathrm{H}_{2} \mathrm{O}, 100\right)$; HRMS $(\mathrm{ESI}+)$ : calculated for $\mathrm{C}_{17} \mathrm{H}_{23} \mathrm{O}_{5}\left([\mathrm{M}+\mathrm{H}]^{+}\right) 307.1540$, found 307.1539 [ $\left.\Delta 0.3 \mathrm{ppm}\right]$. 
<smiles>[2H]C12C=CC(=O)COC1COC(C)O2</smiles>
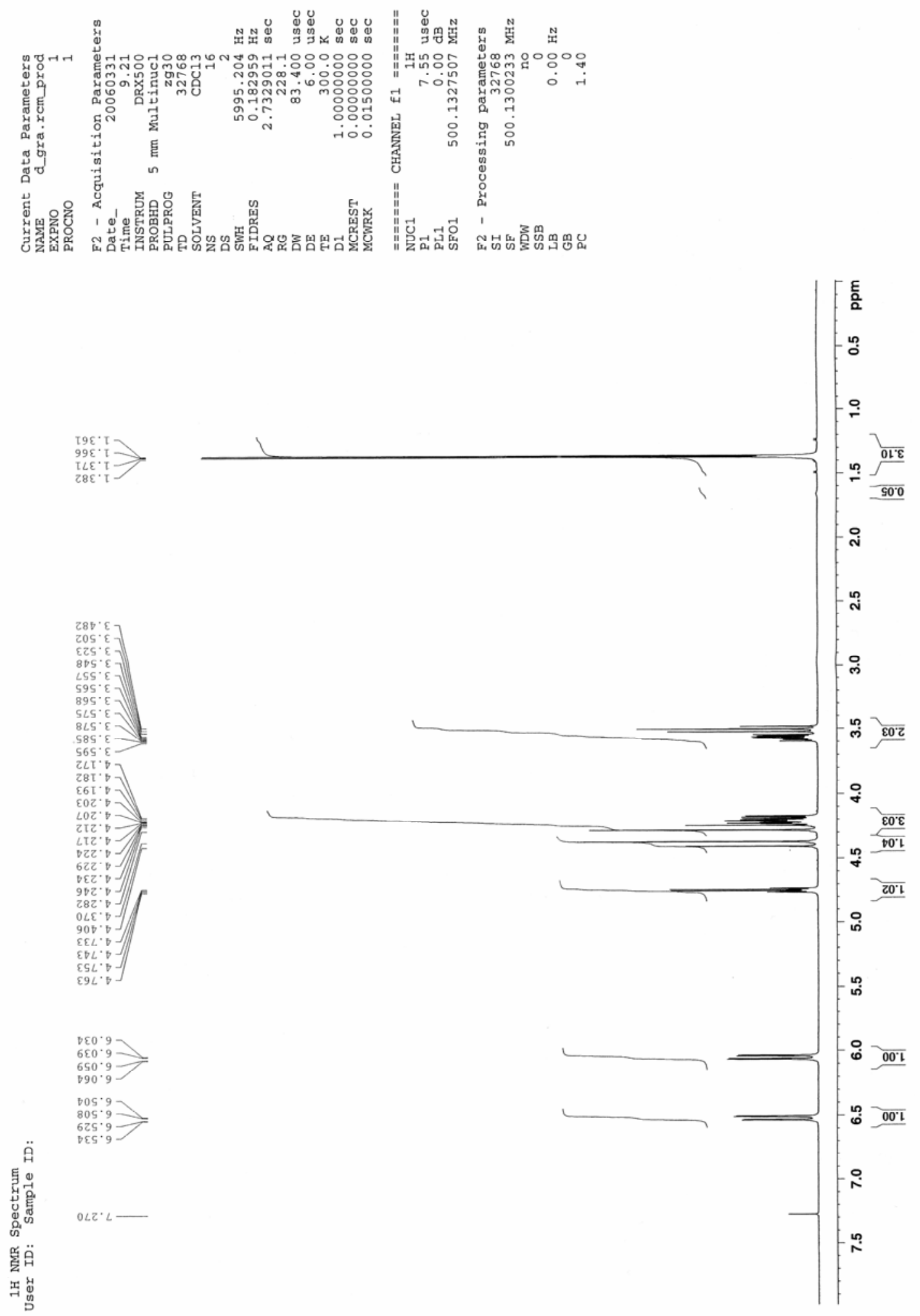
<smiles>CC1OCC2OCC(=O)C=CC2(O)O1</smiles>

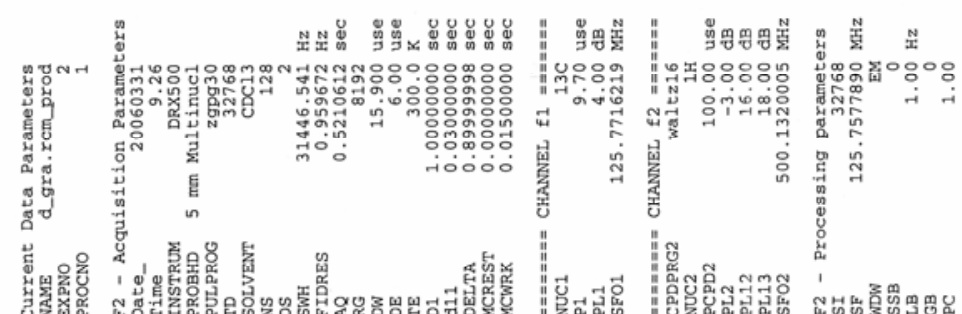

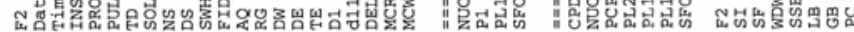

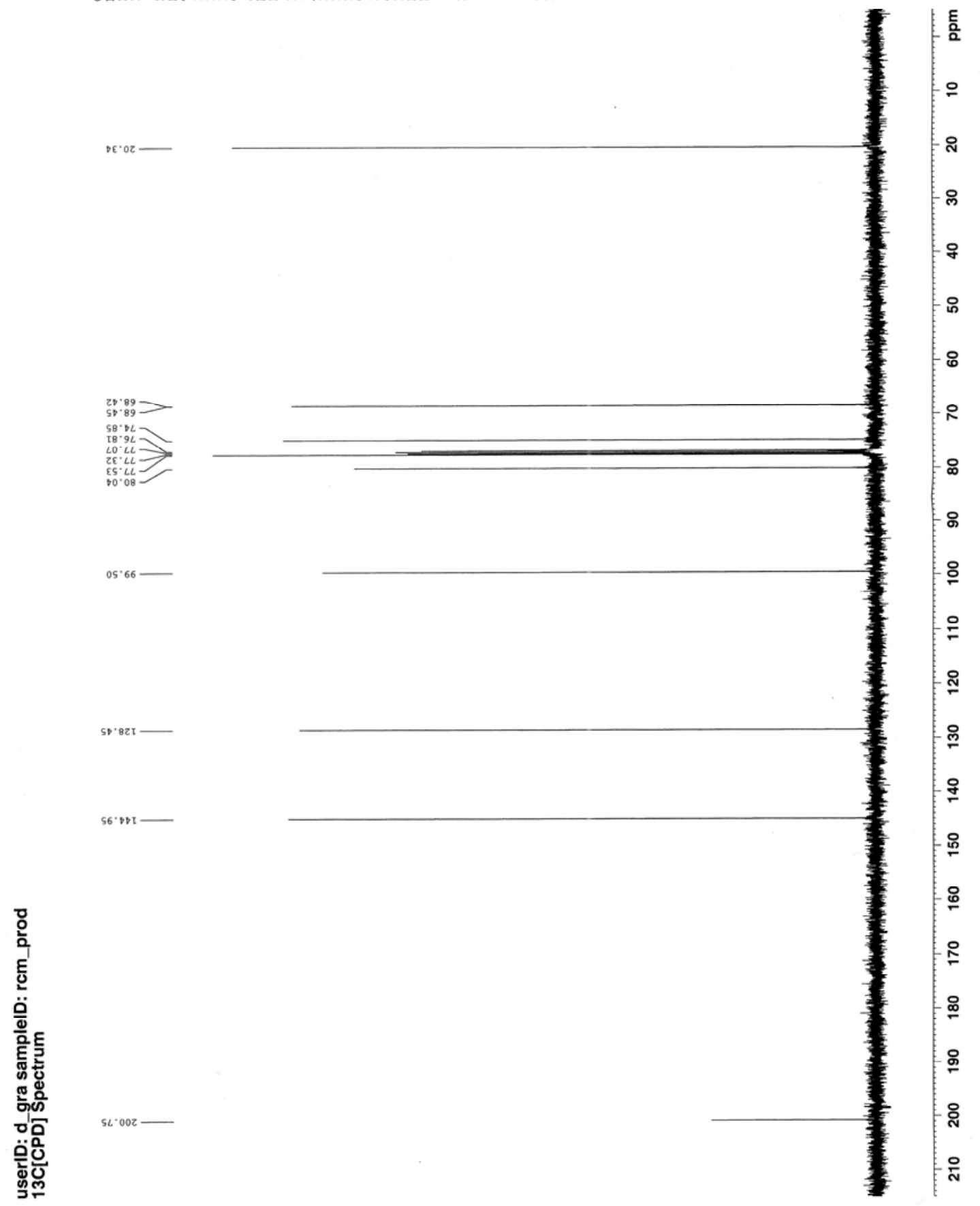



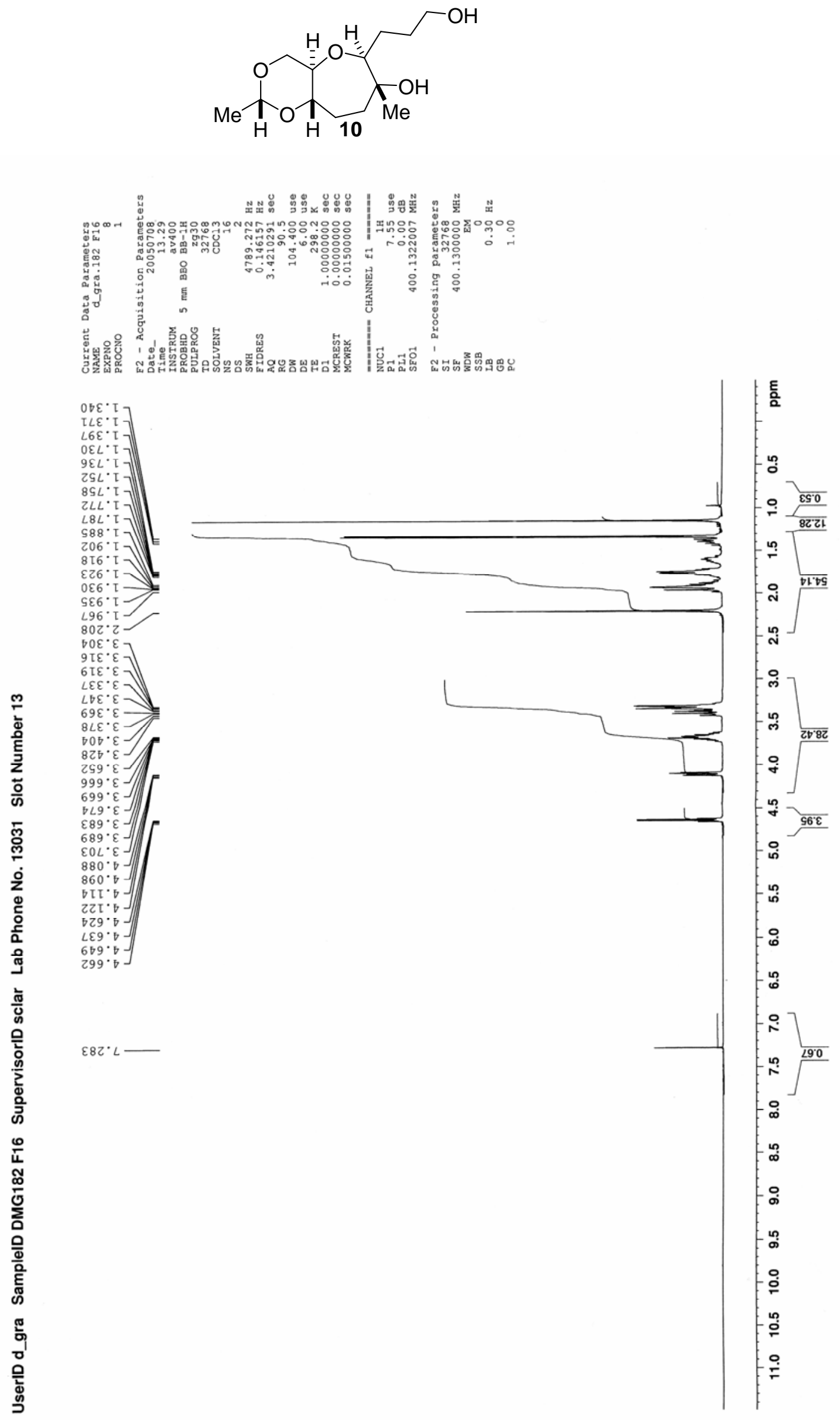
<smiles>CC1OC[C@H]2O[C@H](CCCO)C(C)(O)C[C@H](O)[C@H]2O1</smiles>

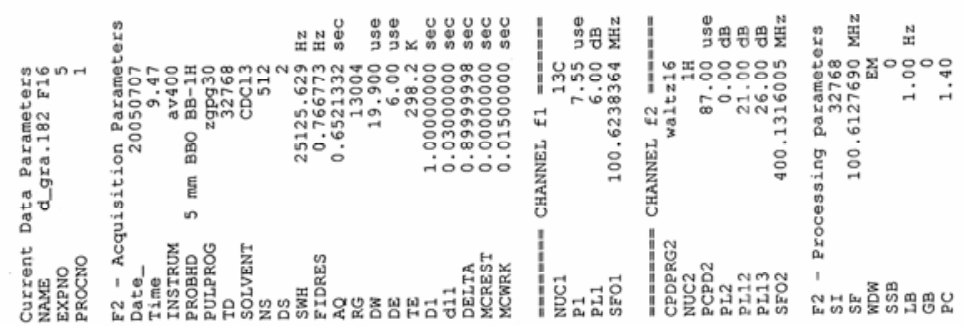

$b b \cdot 0 z=$
$8 L \cdot \varepsilon z=$
$b 9 \cdot 9 z=$
$z b \cdot c z=$
$0 \cdot 62$
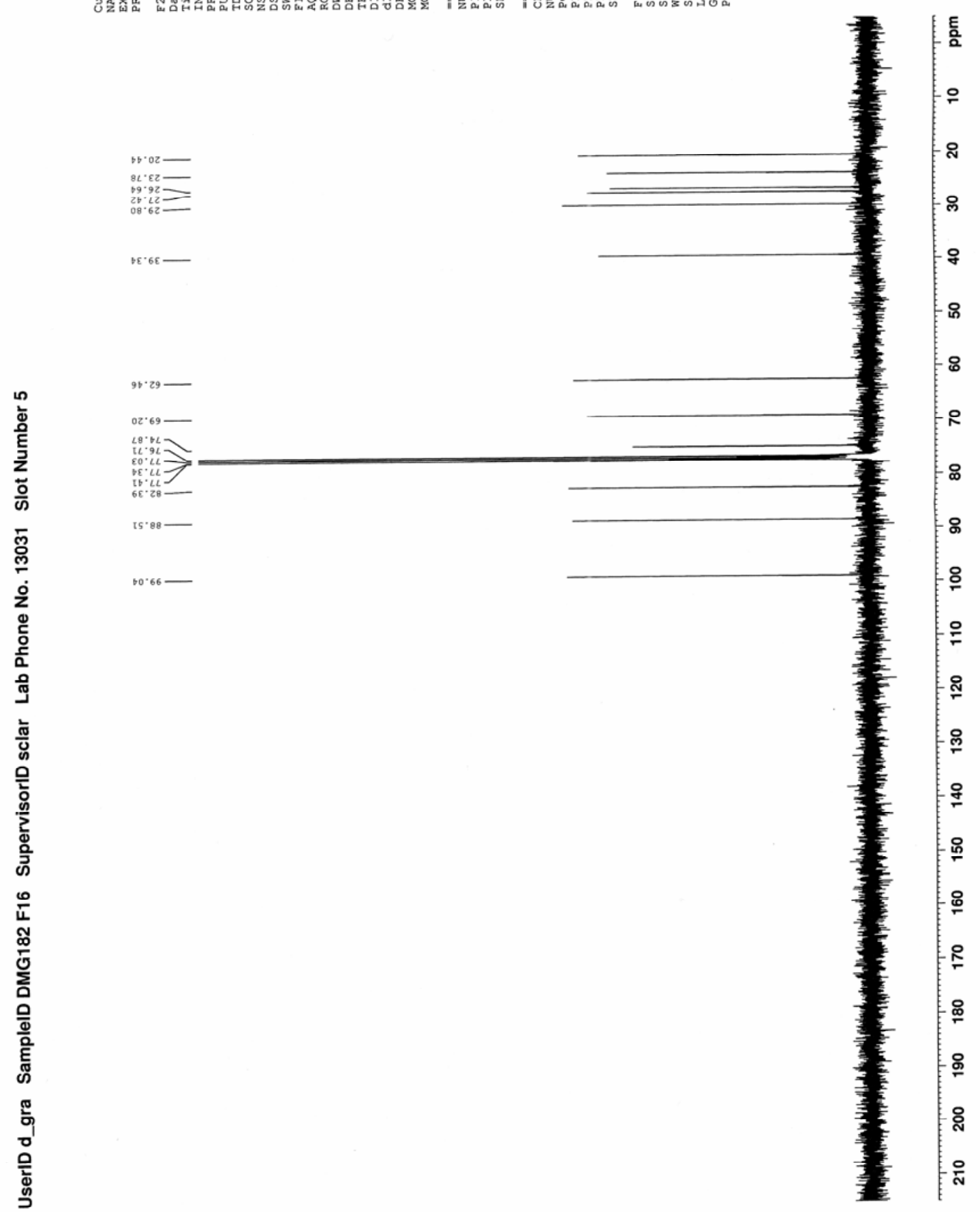

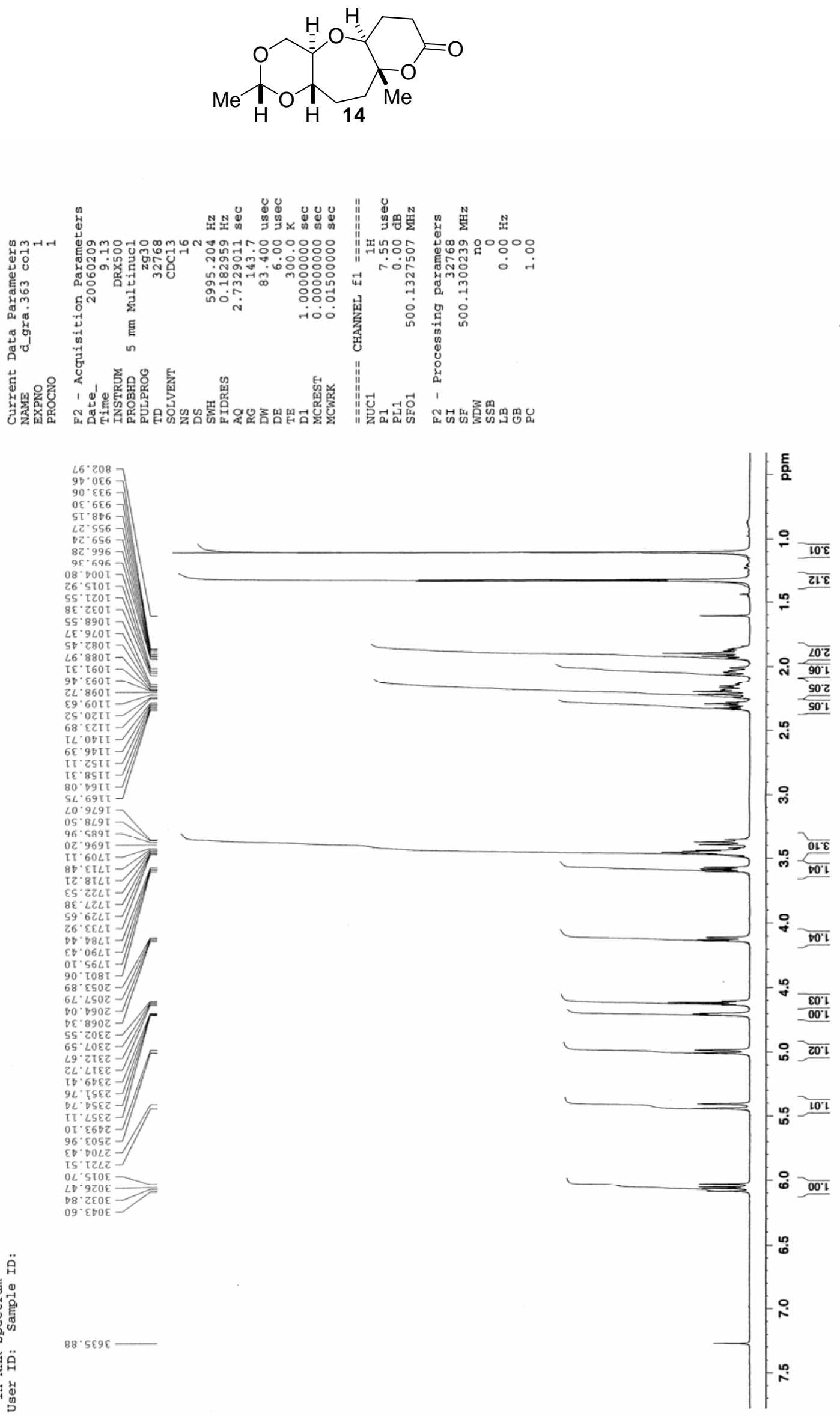

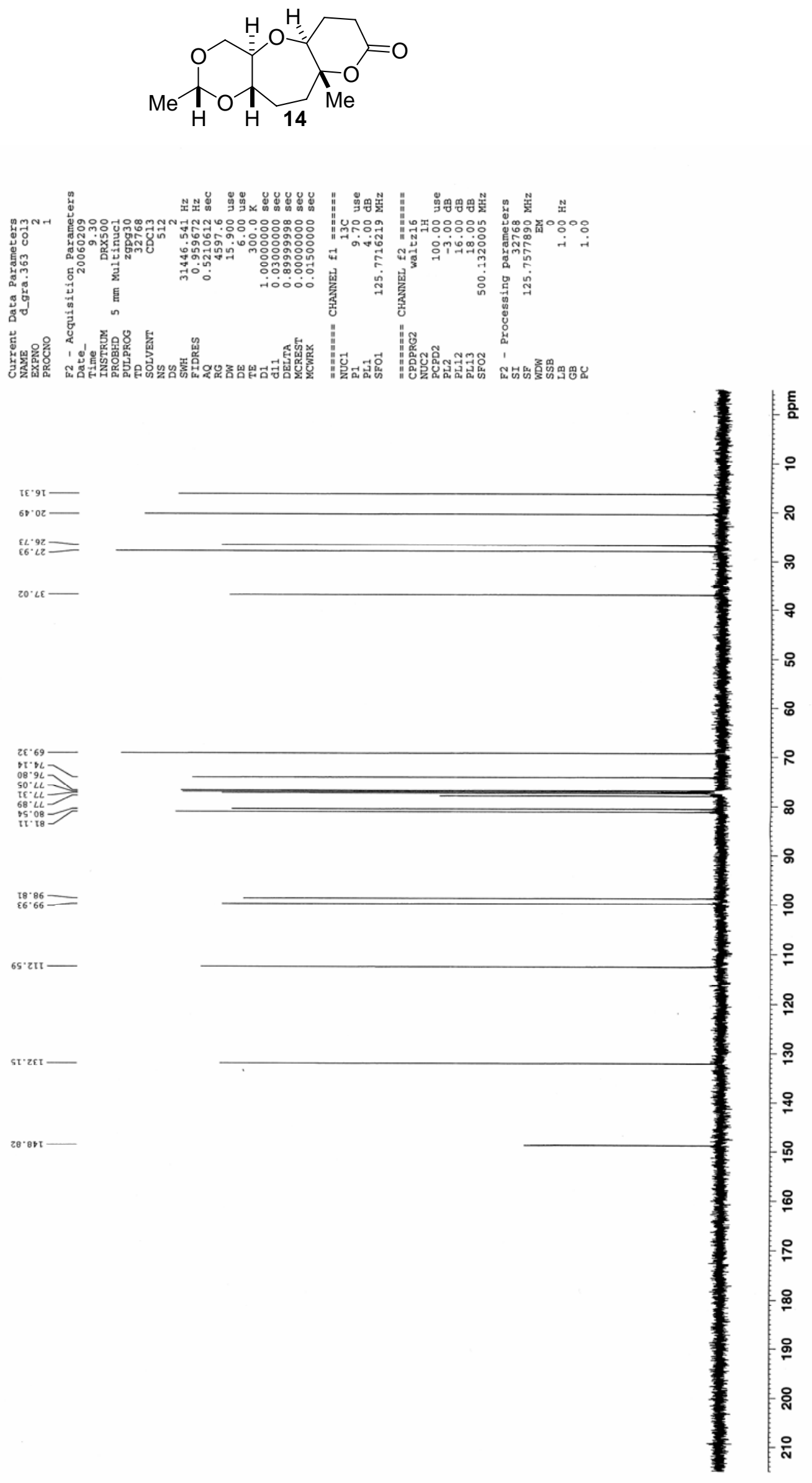

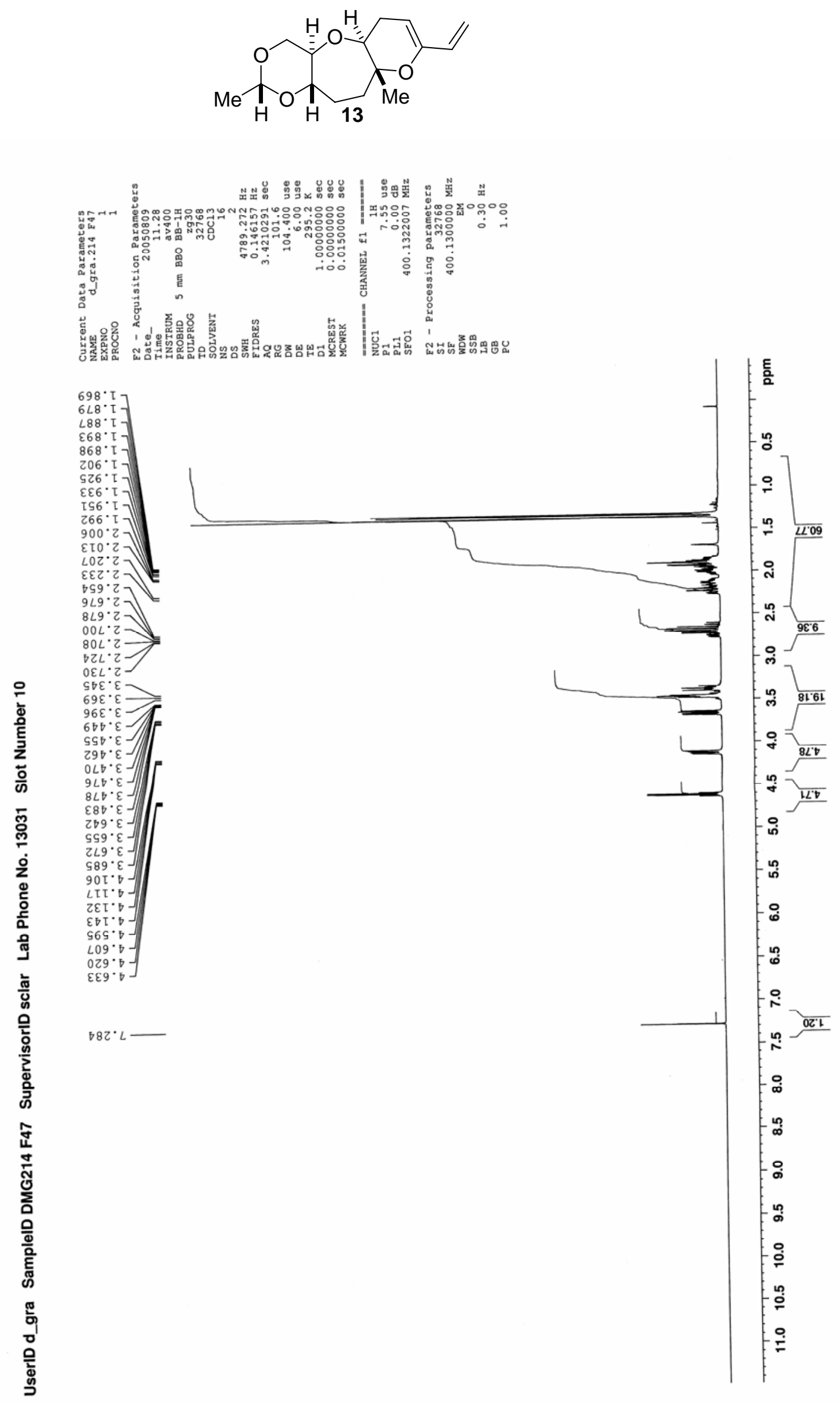
<smiles>C=CC1=CC[C@@H](O[C@@H]2COC(C)O[C@H]2C)[C@](C)(C[13CH3])O1</smiles>

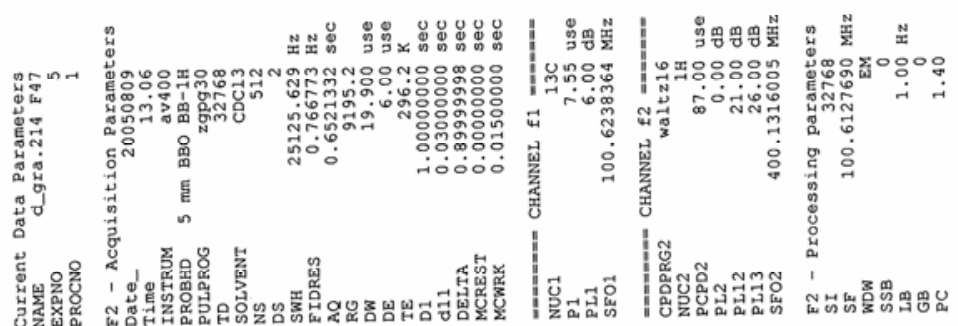

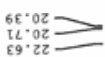

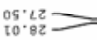

${ }_{02}^{2}<\varepsilon-$

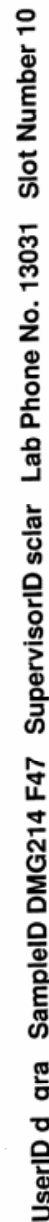

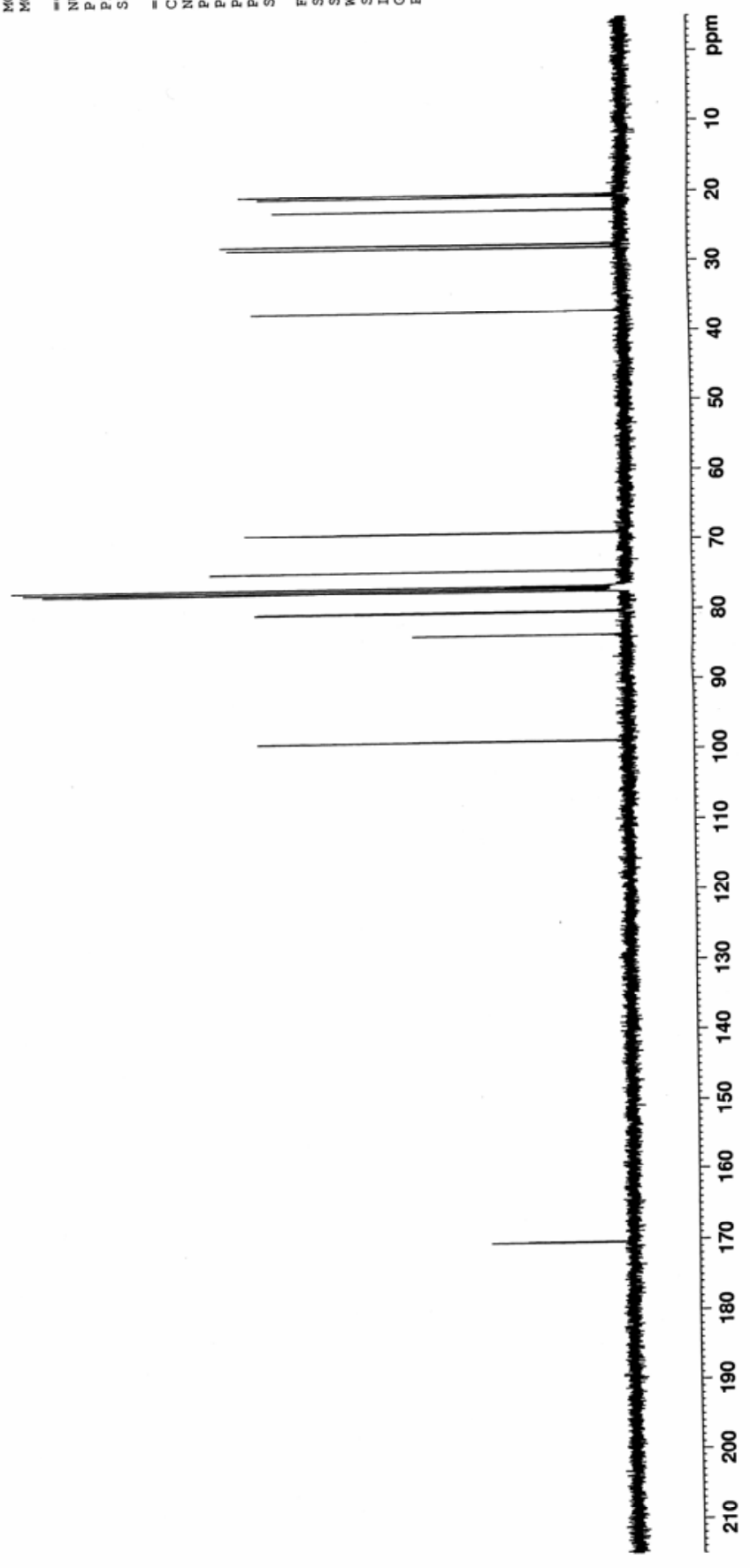



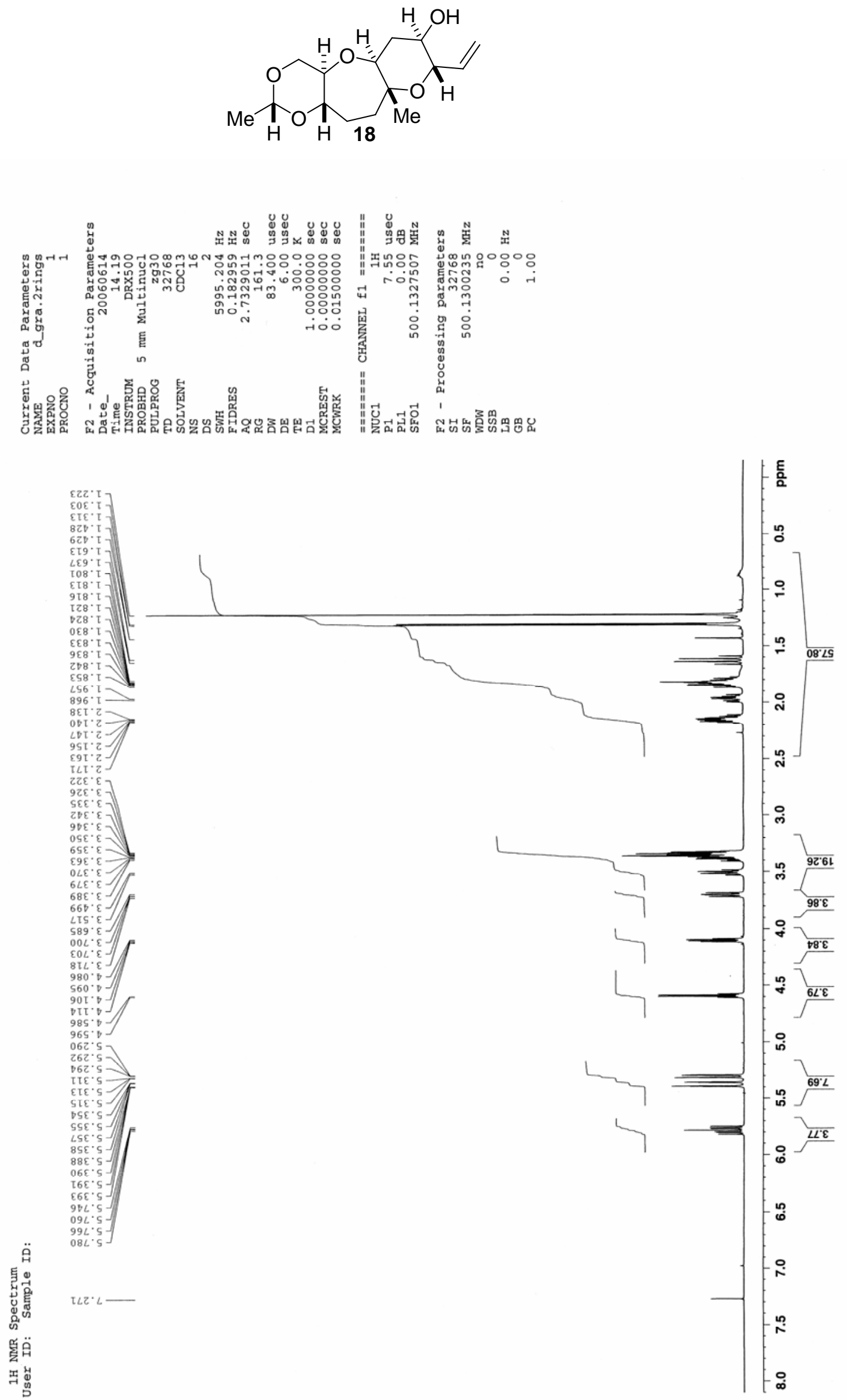


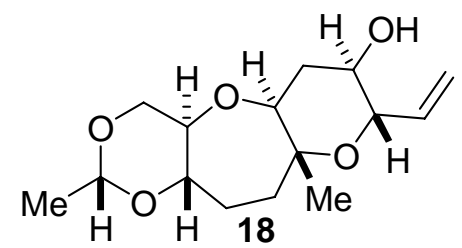

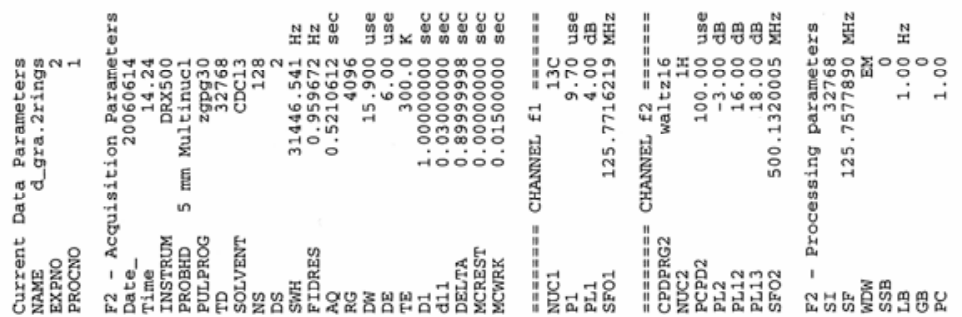

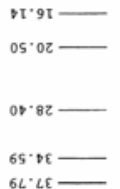

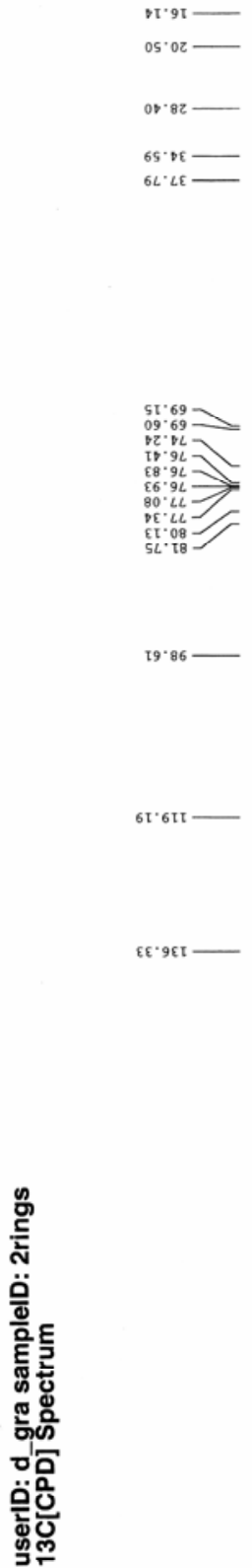

t9:86

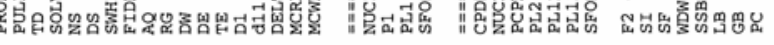

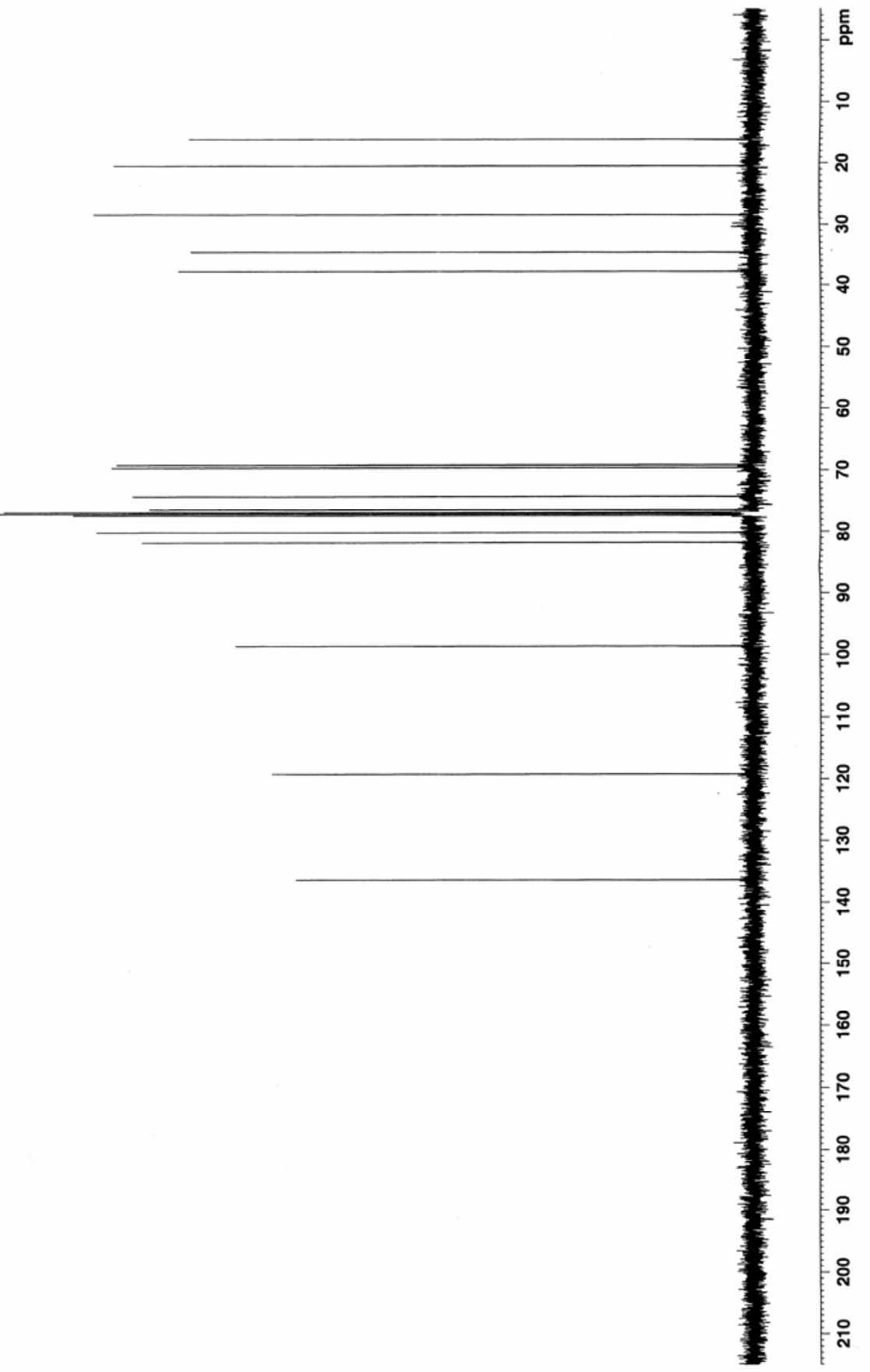



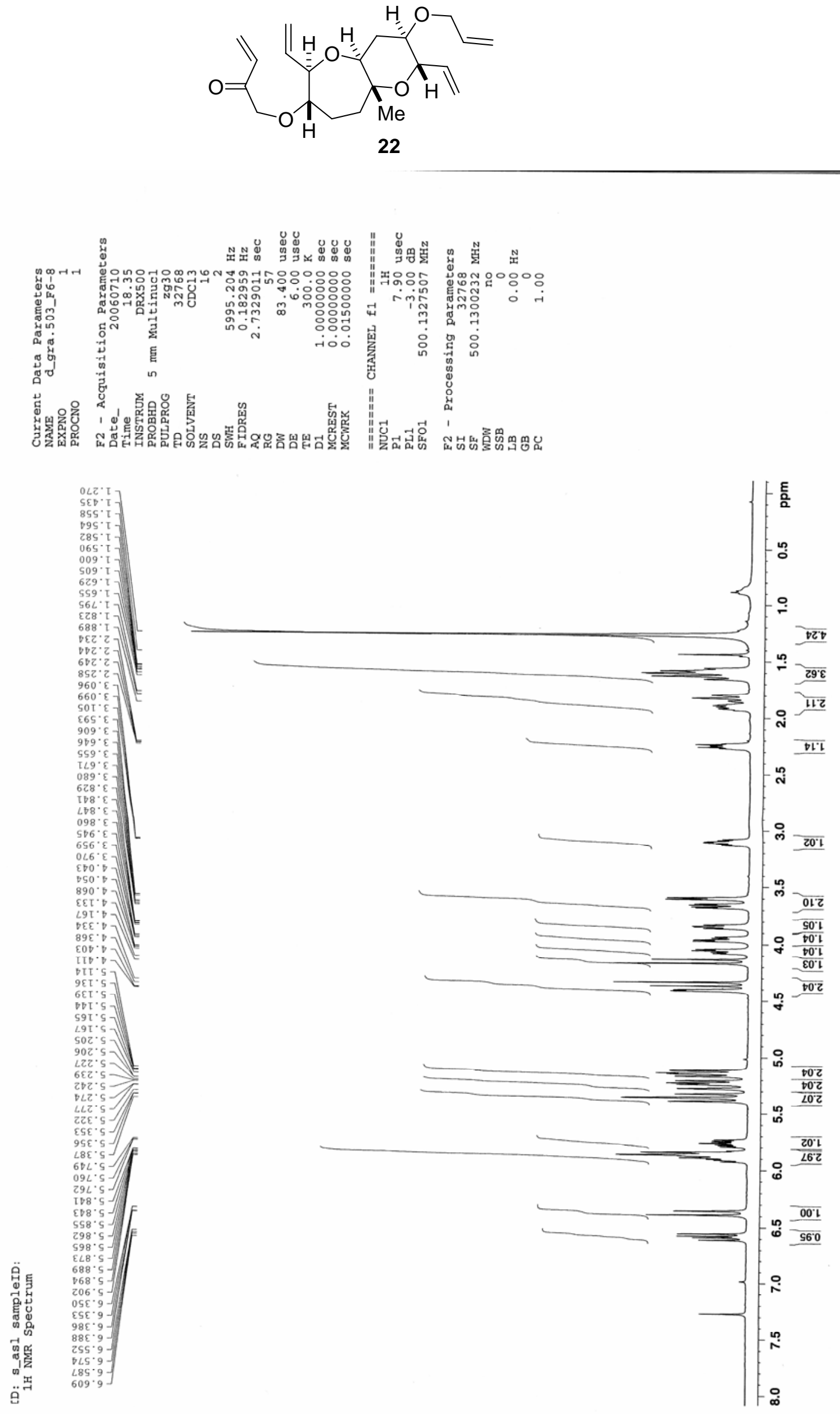

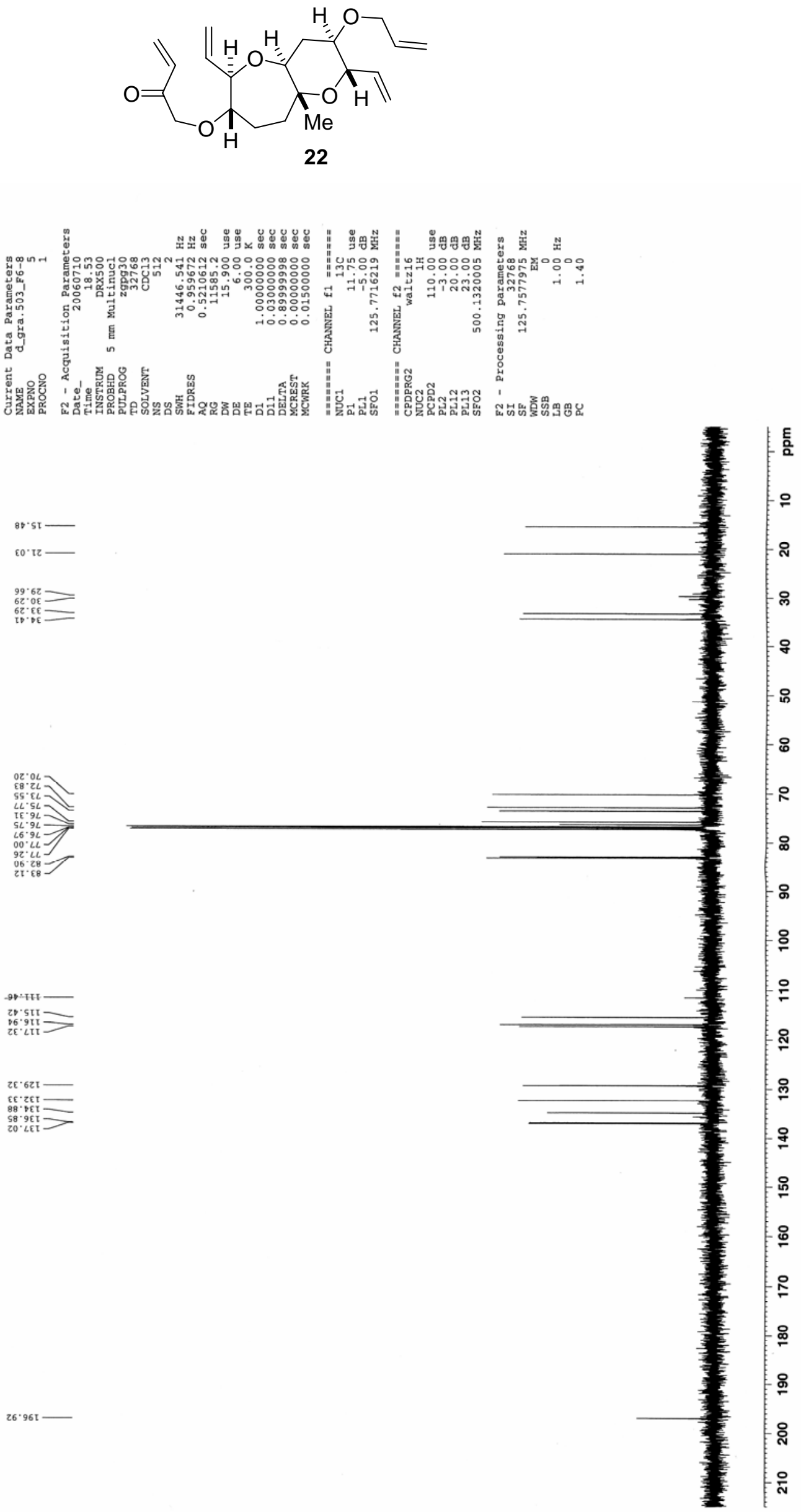

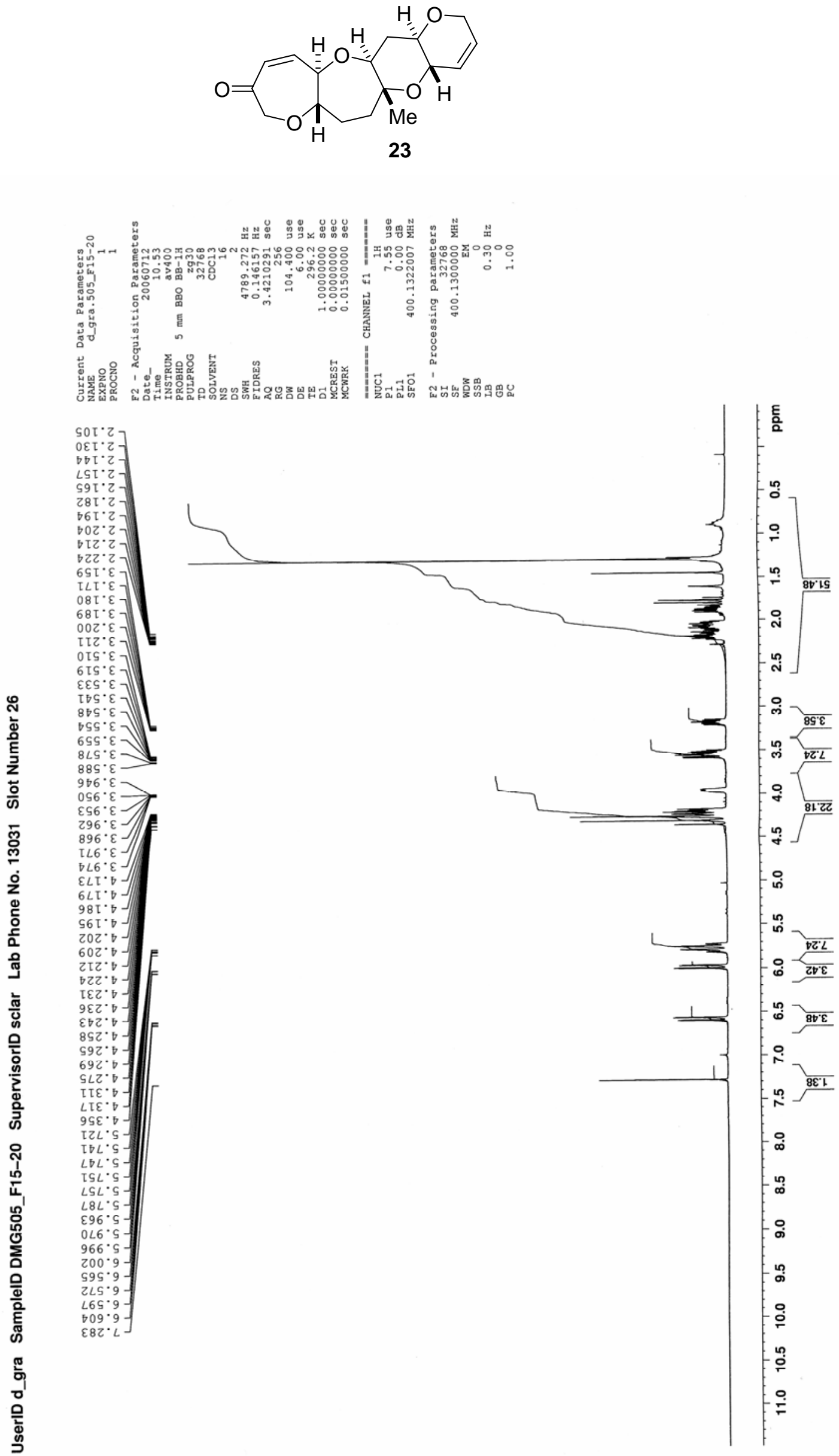
<smiles>C[C@]12CC[C@@H]3OCC(=O)C=C[C@@H]3O[C@H]1C[C@@H]1OCC=C[C@H]1O2</smiles>

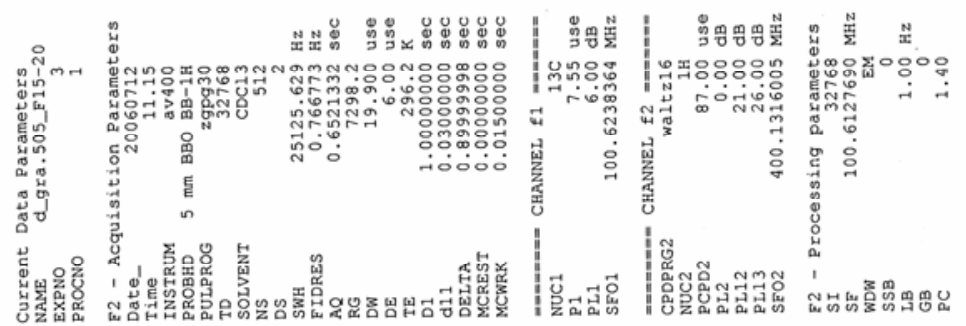

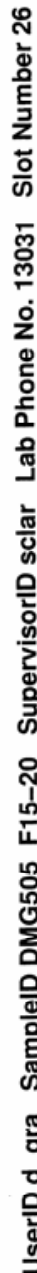

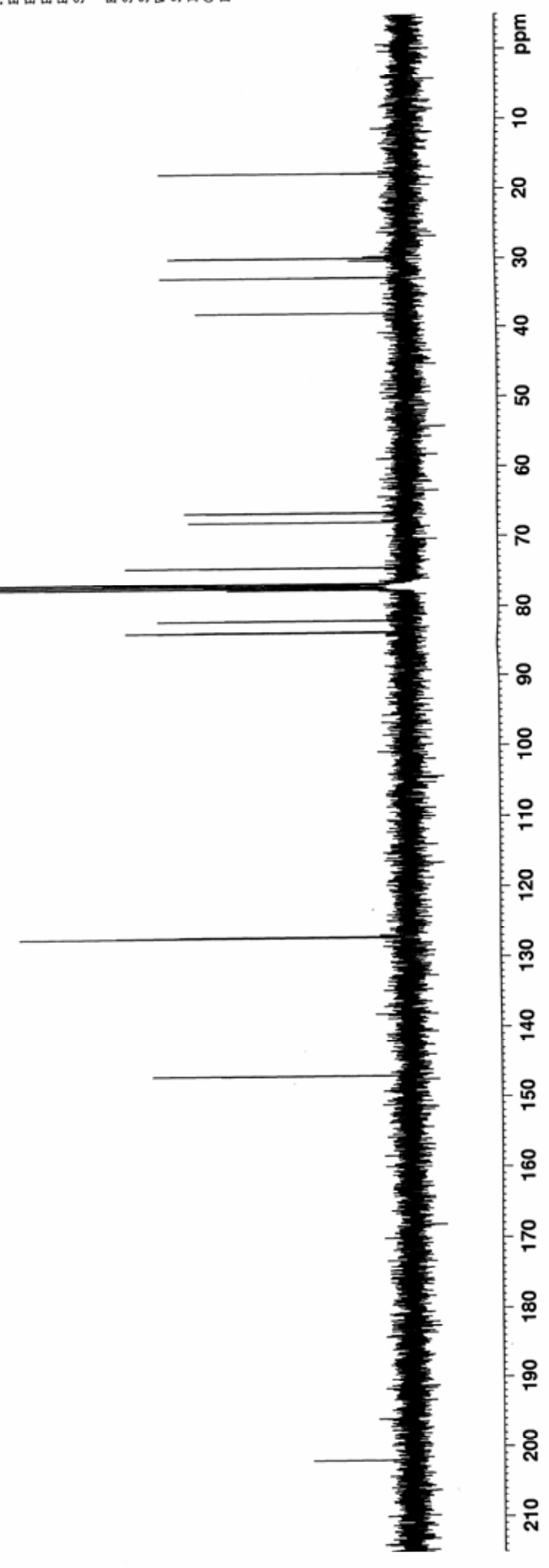

